\title{
COMS-Based Retrieval of Daily Actual Evapotranspiration over Korea
}

\author{
Na-Yeon Park, ${ }^{1}$ Jae-Dong Jang, ${ }^{1}$ Youngmi Kim, ${ }^{2}$ Eun-Ha Sohn, ${ }^{1}$ Mi-Lim Ou, ${ }^{3}$ \\ Jun-Dong Park, ${ }^{1}$ Minji Seo, ${ }^{4}$ Kyeong-Sang Lee, ${ }^{4}$ and Kyung-Soo Han ${ }^{4}$ \\ ${ }^{1}$ National Meteorological Satellite Center, Korea Meteorological Administration, Jincheon-gun 27803, Republic of Korea \\ ${ }^{2}$ National Institute of Meteorological Sciences, Korea Meteorological Administration, Seogwipo-si 63568, Republic of Korea \\ ${ }^{3}$ Climate Change Monitoring Bureau, Korea Meteorological Administration, Seoul 07062, Republic of Korea \\ ${ }^{4}$ Department of Spatial Information Engineering, Pukyong National University, Busan 48513, Republic of Korea \\ Correspondence should be addressed to Kyung-Soo Han; kyung-soo.han@pknu.ac.kr
}

Received 27 April 2017; Accepted 22 June 2017; Published 29 November 2017

Academic Editor: Saro Lee

Copyright (C) $2017 \mathrm{Na}$-Yeon Park et al. This is an open access article distributed under the Creative Commons Attribution License, which permits unrestricted use, distribution, and reproduction in any medium, provided the original work is properly cited.

Evapotranspiration (ET) from the land surface is an important hydrometeorological factor in the exchange of energy between the atmosphere and land surface. The accurate quantification for management of water resources and understanding of climate change are crucial, requiring continuous temporal and spatial monitoring. The objective of this study is to apply and estimate daily actual ET using semiempirical method, B-method, which is based on surface energy balance over heterogeneous area, Korea. To estimate daily ET, we used geostationary meteorological satellite data (Communication, Ocean and Meteorological Satellite, COMS) and polarorbiting satellite data (Système Pour l'Observation de la Terre, SPOT). Estimated daily ET using only satellite data was relatively accurate and reflects land surface characteristics. It had high periodicity and spatial resolution over a wide area on clear-sky days. The daily ET was overestimated by about $1 \mathrm{~mm}$ /day at the two flux tower measurements sites, but the simulated seasonal variation and pattern were in good agreement with flux tower measurements. In the mixed forest, the root-mean-square error (RMSE) was $0.94 \mathrm{~mm} /$ day and the bias was $1.05 \mathrm{~mm} /$ day, while, in the rice paddy, RMSE was $1.12 \mathrm{~mm} /$ day and bias was $1.21 \mathrm{~mm} /$ day.

\section{Introduction}

Evapotranspiration (ET) from land surfaces, which drives latent heat flux (expressed in $\mathrm{mm} /$ day), is the sum of water loss from plant transpiration and water evaporation from land surfaces. An ET of $1 \mathrm{~mm} /$ day is equivalent to a loss of 10,000 liters per hectare per day [1]. It is a phenomenon in which liquid water changes to vapor, resulting in the transfer of water and energy between land surfaces and the atmosphere. As such, it is one of the most important components in the water cycle, representing total water consumed by plants and evaporated from water bodies and nonvegetated surfaces. A recent estimate of global ET components was obtained using a multimodel output from the Global Soil Wetness Project (GSWP) 2, which found that $48 \%$ of mean global ET came from transpiration, 36\% from soil evaporation, and 16\% from canopy ET [2]. ET is an essential variable for understanding surface energy balance (SEB), the global water cycle, and water and vegetation dynamics in terrestrial ecosystems [3-8].

ET plays a critical role in the global water cycle. On a global basis, the mean land surface ET accounts for approximately $60 \%$ of mean precipitation $[9,10]$. At regional scales, ET consumes $>90 \%$ of annual rainfall, and agricultural regions are of crucial importance for water resource management in arid and semiarid climates $[11,12]$, highlighting the importance of accurate ET estimates. There are several methods for in situ measurement of ET including pan evaporation (large/small), atmometers, evapotranspirometers tanks, lysimeters, Bowen ratio [13] based on meteorological data, the eddy covariance method using flux tower measurements, and scintillometers [14]. Although in situ measuring methods provide accurate values at point scales, they offer limited spatiotemporal representation and are complex, labor intensive, and expensive, particularly in forests where ET retrieval is more difficult due to the evident experimental limitations [15]. 
Satellite remote-sensing method provides a wide range of coverage, frequent updates, and consistent quality. Several methods have been developed to estimate ET from remotesensing data including empirical and statistical methods with remotely sensed vegetation indices [16-18], physical models that calculate ET as the residual of SEB using remotely sensed thermal infrared (IR) data [19-25], and other physical models such as the Penman-Monteith equations [26], the revised Resistance-Surface energy balance and the PenmanMonteith (RS-PM) equations [27-29] and Priestley-Taylor equations [30-32]. On a global or continental scales, the spatial ET is provided by the European Organization for the Exploitation of Meteorological Satellites (EUMETSAT) Satellite Application Facility (SAF) on Land Surface Analysis (LSA) and the National Aeronautics and Space Administration (NASA). EUMETSAT LSA SAF has developed ET products over large areas (Europe, Africa, and South America) using the spinning enhanced visible and IR imager onboard Meteosat Second Generation (MSG) [33]. It provides $30 \mathrm{~min}$ and daily ET estimates with a $3 \mathrm{~km}$ spatial resolution at nadir. It is based on a simplified Soil-Vegetation-Atmosphere Transfer (SVAT) model that uses a combination of remotesensing and meteorological data from the European Center for Medium-Range Weather Forecast (ECMWF) as inputs. The range of LSA SAF daily ET values is $0-10 \mathrm{~mm} /$ day with $20 \%$ uncertainty, and the product is highly correlated (85-95\%) with ECMWF products. Due to limited validation in dry or very dry conditions (mainly in Africa), care should be taken when using the product [34]. NASA has developed ET products over global terrestrial regions using the MODerate-resolution Imaging Spectrometer (MODIS) on the Aqua and Terra satellites. It provides 8-day, monthly, and yearly ET with a $1 \mathrm{~km}$ resolution. It is based on PenmanMonteith equations, which use a combination of remotesensing data and meteorological data from NASA's Global Modeling and Assimilation Office (GMAO, v4.0.0) as inputs. MODIS ET has been validated using 46 AmeriFlux towers [27].

The semiempirical method using remote-sensing data, well-known approaches, proposed by [35], which is based on the SEB, uses the linear relationship between the sensible heat flux and the difference between surface and air temperatures near the land surface. The net integrated daily ET at the surface can be obtained from surface and air temperatures measured near the time of the local maximum ("net integrated daily radiation"), which is considered a semiempirical method. The B-method is determined either by fitting the linear least squares to the data or by simulations based on a SVAT [36-38] or boundary layer model. Many studies using the B-method have shown that the error of estimated daily ET is about $\pm 1 \mathrm{~mm} /$ day; $B$ coefficients depend on surface roughness, wind speed, and atmospheric stability $[39,40]$.

Remote-sensing based ET estimation using B-method has been reported in many previous studies. This method can be used to estimate ET at the continental scale (e.g., for drought detection, water-reserve estimations for irrigation [41], and rainfall monitoring in Sahel regions [42, 43]); at the local scale (e.g., grasslands [12], wheat fields and meadows [41], and sugar beets and wheat stump [39]); and at the regional scale (e.g., barley fields $[10 \times 10 \mathrm{~km}]$ in a semiarid region of Spain using the Advanced Very High Resolution Radiometer sensor onboard the National Oceanic Atmosphere Administration (NOAA) satellite [44], in a northern boreal forest region of Finland using the MODIS sensor [15], and in western Québec, Canada (approximately $224,000 \mathrm{~km}^{2}$ ), using NOAA visible and GOES thermal IR satellite data [45]). B-method was designed to simplify surface energy budget through the semiempirical way, which determine $B$-coefficient for specific land type. It means that this method has a limitation to obtain the spatially gridded information over wide area covering various land types. It could be solved through $B$-coefficient generation model adapting over various land types, which is firstly proposed for northeast Asia region, in this study.

The objective of this study is (1) to estimate the daily actual ET using semiempirical method, B-method, considering various type of land cover and surface roughness in heterogeneous regions, Korea, by using geostationary meteorological satellite data (Communication, Ocean and Meteorological Satellite, COMS) and polar-orbiting satellite data (Système Pour l'Observation de la Terre, SPOT) and (2) to evaluate estimated daily actual ET derived from B-method using flux tower ET measurements and compare it to MODIS averaged 8-day ET (MOD16).

\section{Theory and Data}

2.1. Theory. The simplified semiempirical regression method used in this study was first proposed by [35] and is based on the land-SEB equation using thermal IR data, from which land surface temperature can be extracted. The energy arriving at the surface is equal to the energy leaving the surface during the same period. All of the fluxes of energy should be considered when deriving an SEB equation, which can be expressed as follows:

$$
\mathrm{Rn}=\mathrm{LE}+H+G
$$

where $\mathrm{Rn}$ is the net radiation $\left(\mathrm{W} / \mathrm{m}^{2}\right), \mathrm{LE}$ is the latent heat flux (energy consumed by ET; $\mathrm{W} / \mathrm{m}^{2}$ ), $H$ is the sensible heat flux $\left(\mathrm{W} / \mathrm{m}^{2}\right)$, and $G$ is the ground heat flux $\left(\mathrm{W} / \mathrm{m}^{2}\right)$. Many studies estimating daily ET have assumed that ground heat flux is a negligible part of the daily energy balance, and therefore set $G$ to 0 because the magnitude of daily or 10-day soil heat flux is relatively small compared to net radiation [46]. Therefore, LE is calculated as the remaining difference between $\mathrm{Rn}$ and $H$ :

$$
\mathrm{ET} \approx \mathrm{LE}=\mathrm{Rn}-H .
$$

Although the net radiation can be derived through remote-sensing data, the sensible heat flux is complex and cannot be easily obtained. The numerous meteorological variables involved (e.g., wind speed, relative humidity, and atmosphere pressure) make it difficult to calculate ET. Therefore, in this study, we used the simplified method proposed by [35] to estimate daily actual ET. The method is based on the linear relationship between the sensible heat flux and the difference between instantaneous surface and air temperatures measured near midday (about 13:00-14:00 local time) 
over diverse surfaces with variable vegetation cover [3]. The simplified regression method can be expressed as follows:

$$
\mathrm{ET}_{d}-\mathrm{Rn}_{d}=-B_{d} \cdot\left(T_{S_{\mathrm{mid}}}-T_{a_{\mathrm{mid}}}\right),
$$

where $\mathrm{ET}_{d}$ is the daily actual ET (mm/day), $\mathrm{Rn}_{d}$ is the daily net radiation ( $\mathrm{mm} /$ day), $B_{d}$ is a semiempirical coefficient $\left(\mathrm{mm} /\right.$ day/K), $T_{S_{\text {mid }}}$ is the land surface temperature $(\mathrm{Ts})(\mathrm{K})$ of midday, and $T_{a_{\text {mid }}}$ is the near-surface air temperature (Ta) $(\mathrm{K})$ of midday.

\subsection{Study Area and Data}

2.2.1. Study Area. The study area covered $220,847 \mathrm{~km}^{2}$ $(1,100 \mathrm{~km}$ from north to south) of the Korea, adjacent to the western Pacific Ocean $\left(33-43^{\circ} \mathrm{N}, 122-132^{\circ} \mathrm{E}\right.$; Figure 1$)$. The climate is considered temperate, with four distinct seasons. On average, the warmest month is August, while January is the coldest. The humidity is highest in July, reaching 80-90\%, and lowest in January and April (30-50\%). The study area had various types of land cover, including water, evergreen coniferous forests $(0.06 \%)$, deciduous broadleaf forests $(4.07 \%)$, mixed forests $(56.96 \%)$, savannas $(0.06 \%)$, grasslands $(0.74 \%)$, permanent wetlands $(0.01 \%)$, croplands/natural vegetation mosaics (36.05\%), developed urban areas $(2.01 \%)$, snow/ice $(0.003 \%)$, and barren or sparsely vegetated areas $(0.032 \%)$, as identified by the MODIS International Geosphere Biosphere Programme (IGBP) land cover map from 2012. There were mainly croplands in the western region and mixed forests in the eastern region.

2.2.2. Data. Figure 2 shows the components of the surface energy balance (i.e., net radiation [Rn], air temperature [Ta], and $B$-coefficients) for derived daily actual ET algorithm. We used the geostationary orbit satellite (COMS) and polar orbit satellite-based input variables for estimate daily actual ET algorithms.

(1) COMS Data. COMS, the first Korean geostationary meteorological satellite, was launched successfully on 27 June 2012 and has been operating at $128.2^{\circ} \mathrm{E}$ since April 1, 2012. The meteorological imager (MI) onboard COMS has five channels, which include one visible channel $(1 \mathrm{~km}$; $0.55-0.8 \mu \mathrm{m})$ and four IR channels $(4 \mathrm{~km}$, shortwave IR [SWIR]; 3.5-4.0 $\mu \mathrm{m}$, water vapor; $6.5-7.0 \mu \mathrm{m}$, IR1; 10.3$11.3 \mu \mathrm{m}$, IR2; $11.5-12.5 \mu \mathrm{m})$ with $15 \mathrm{~min}$ acquisition intervals over the extended northern hemisphere. Although its high temporal resolution and ability to provide 96 daily acquisitions are advantageous, its spatial resolution at nadir $(4 \mathrm{~km})$ is low. The COMS Level 1 product (IR1, IR2, and visible) and COMS Level 2 product (land surface temperature [LST] and insolation [INS]) were used to estimate daily ET. Land surface temperatures were estimated using the split-window technique with a spatial resolution of $4 \mathrm{~km}$. Compared to MODIS LST product, the COMS LST product has a root-mean-square error (RMSE) of $3.12 \mathrm{~K}$ and a bias of $-1.65 \mathrm{~K}$. It used the mean values 13:00-14:00 local time. COMS INS product was estimated using the physical model [47] for clear and cloudy skies with a spatial resolution of $4 \mathrm{~km}$ using daily mean values. Compared to pyranometer measurements, the COMS INS product has an RMSE of $60-140 \mathrm{~W} / \mathrm{m}^{2}$.

(2) SPOT Data. It is critical to understand the effects of vegetation when estimating ET. Transpiration is the dominant component of ET across a variety of ecohydrological systems [2]. Because COMS/MI has no near-IR (NIR) channels and cannot account for the impact of vegetation, we considered these variables using the Normalized Difference Vegetation Index (NDVI) from SPOT satellites, which were launched by the French Centre National d'Etudes Spatiales to observe vegetation. The SPOT satellite is a sun-synchronous polar-orbiting satellite with an inclination of $98.7^{\circ}$ at an altitude of $820 \mathrm{~km}$. The VGT sensor onboard SPOT is a multispectral instrument with a wide swath width $(2,280 \mathrm{~km})$ and a $1 \mathrm{~km}$ spatial resolution. The sensor has four spectral bands: blue $(0.43-0.47 \mu \mathrm{m})$, red $(0.61-0.68 \mu \mathrm{m})$, NIR $(0.78-0.89 \mu \mathrm{m})$, and SWIR $(1.58-1.74 \mu \mathrm{m})$. In this study, the surface reflectance (i.e., surface albedo) was calculated using the SPOT/VGT 10-day synthesis (D10) product corrected Bidirectional Reflectance Distribution function (BRDF) in the red and NIR channels. The BRDF is a critical tool for reliably reducing the anisotropy associated with surface scattering effects, one of the main fluctuating error sources of relative solar-target-sensor geometry [48]. Albedo was determined using monthly mean data from 2001 to 2011. NDVI varies seasonally according to the type of vegetation. To consider of vegetation status over Korea, the NDVI was calibrated using multiple polynomial regression [49]. In addition, geo- and atmosphere-corrected data, as well as S10 data, were used. The S10 data were synthesized in three 10-day sections per month, from days 1-10, days 11-20, and day 21 to the last day, using the maximum value composite method. We also used the Normalized Difference Water Index (NDWI), using NIR and SWIR channels as proposed by [50], to estimate the satellite-based air temperature and account for the effects of drying and wetting conditions of the surface.

(3) Ancillary Data. To derive daily ET, surface roughness length $\left(Z_{0}\right)$, the MODIS land cover map, and a digital elevation model (DEM) were used. $Z_{0}$ is a critical parameter for estimating aerodynamic resistance between the land surface and atmosphere, as well as daily ET, because fluxes of mass and energy in and out of canopies are dependent on turbulent flow. There are many limitations when measuring $Z_{0}$ using satellite data; therefore, it is obtained using indirect methods. In Europe, these data are provided by land cover. In this study, $Z_{0}$ of the forest region was estimated using Ecoclimap$1 \mathrm{DB}[51,52]$, which is a class-based input for global and regional climate models produced in Europe that provides ground information for the same land cover and climate at a $1 \mathrm{~km}$ spatial resolution. In addition, NDVI-based $Z_{0}$ [53] was used in nonforested areas. The DEM used the GTOPO30 data provided by the EROS data center of the United States Geological Survey. GTOPO30 is part of the World Geodetic System 1984 and has a resolution of 30 arcs (about $1 \mathrm{~km}$ or $\left.0.0083333^{\circ}\right)$.

(4) Data Reprocessing and Matchup Data Base (MDB). To reprocess the data for estimating the COMS ET, the remotesensing data (i.e., air temperature, surface temperature, INS, 

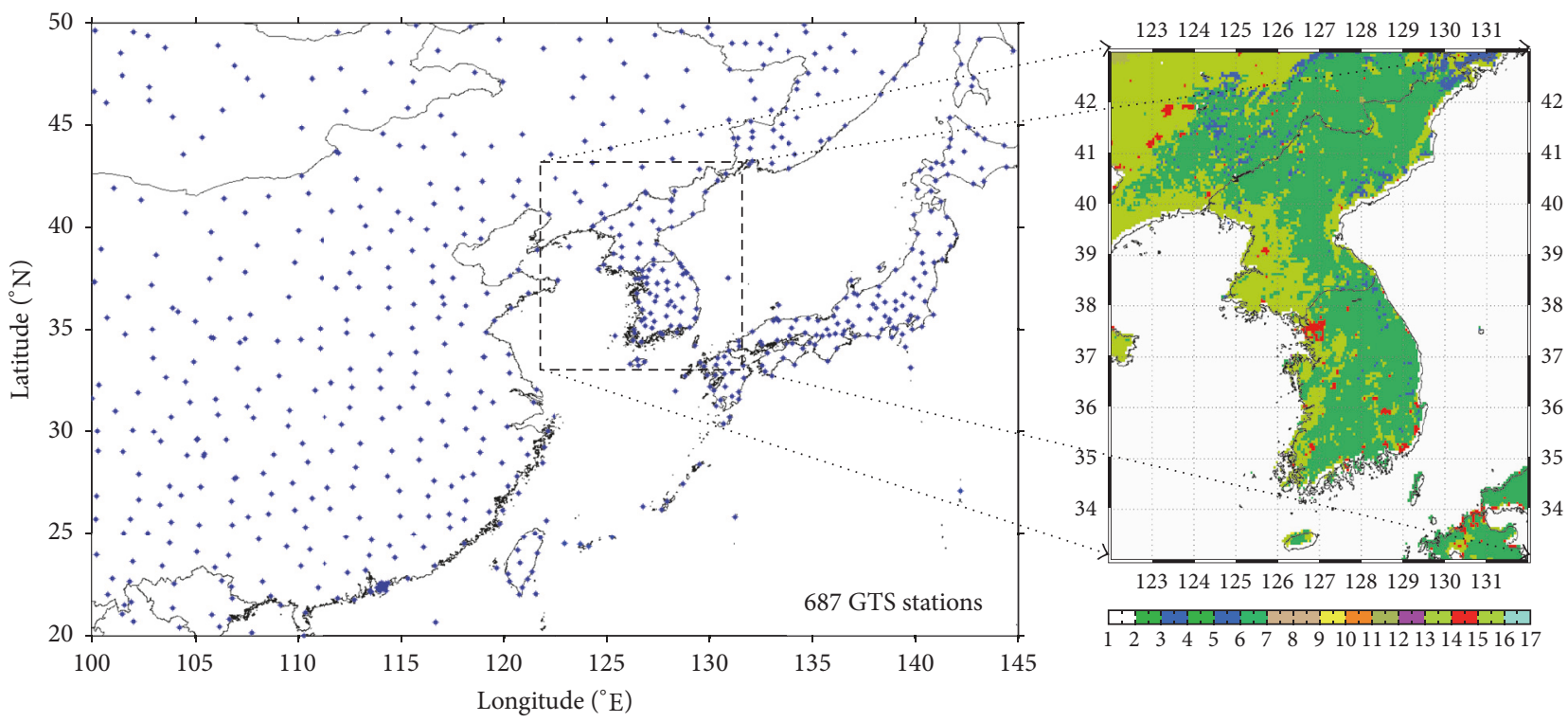

FIgure 1: Location of Korea in this study area. The blue points represent the Global Telecommunication System (GTS) over North-East Asia regions. The right figure represents MODIS land cover types map over Korea (1: water bodies; 2: evergreen needleleaf forest; 3: evergreen broadleaf forest; 4: deciduous needleleaf forest; 5: deciduous broadleaf forest; 6: mixed forest; 7: closed shrublands; 8: open shrublands; 9: woody savannas; 10: savannas; 11: grasslands; 12: permanent wetlands; 13: croplands; 14: urban and built-up; 15: cropland/natural vegetation mosaics; 16: snow/ice; 17: barren or sparsely vegetated).

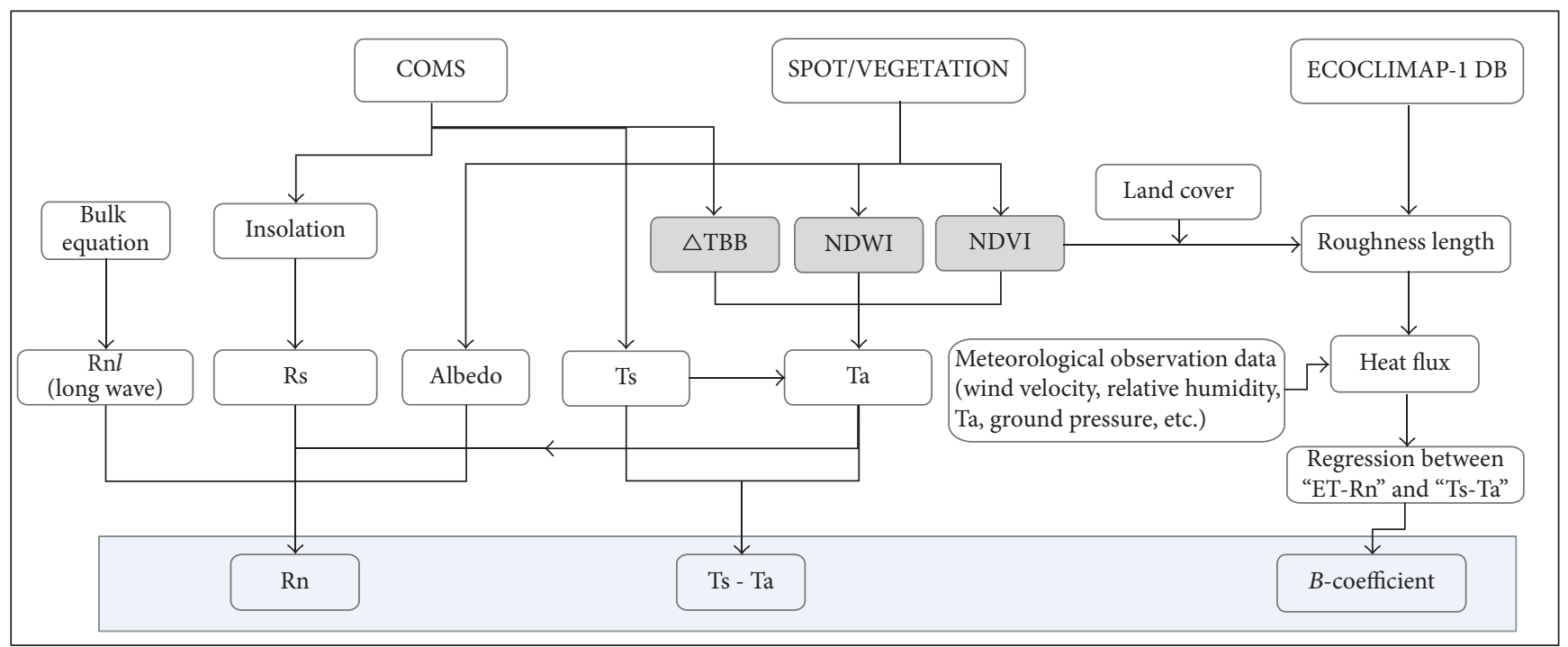

FIGURE 2: The geostationary orbit satellite (COMS), polar orbit satellite (SPOT), and ancillary data (ECOCLIMAP-1 DB) based input variables for estimate daily actual evapotranspiration (ET) algorithms.

albedo, outgoing radiation, vegetation index, land cover map, $Z_{0}$ map, and DEM) and meteorological data (i.e., temperature, wind speed, relative humidity, and atmospheric pressure) must have coincident temporal and spatial resolutions $(1 \mathrm{~km})$. All of the data were standardized to a Plate Carrée projection (Geographic/WGS84 projection) with a $1 \mathrm{~km}$ spatial resolution in the course of 1 year (April 2011 to March 2012) in Korea (33-43 $\left.{ }^{\circ} \mathrm{N}, 122-132^{\circ} \mathrm{E}\right)$. Meteorological observations were collected from a total of 93 observatories (manned observation stations) in Korea. The satellite and auxiliary data were standardized with the meteorological observations by averaging the nearest time and distance (within $1 \mathrm{~km}$ ) around the observation station. The data were analyzed by linear regression of the difference between ET and $\mathrm{Rn}$ and the difference between the surface (Ts) and air temperatures (Ta) observed from 13:00 to 14:00.

(5) Validation Data. To evaluate the accuracy of the COMS daily ET, we used flux tower measurement data and MODIS ET (MOD16) [28]. The flux tower measurements were 


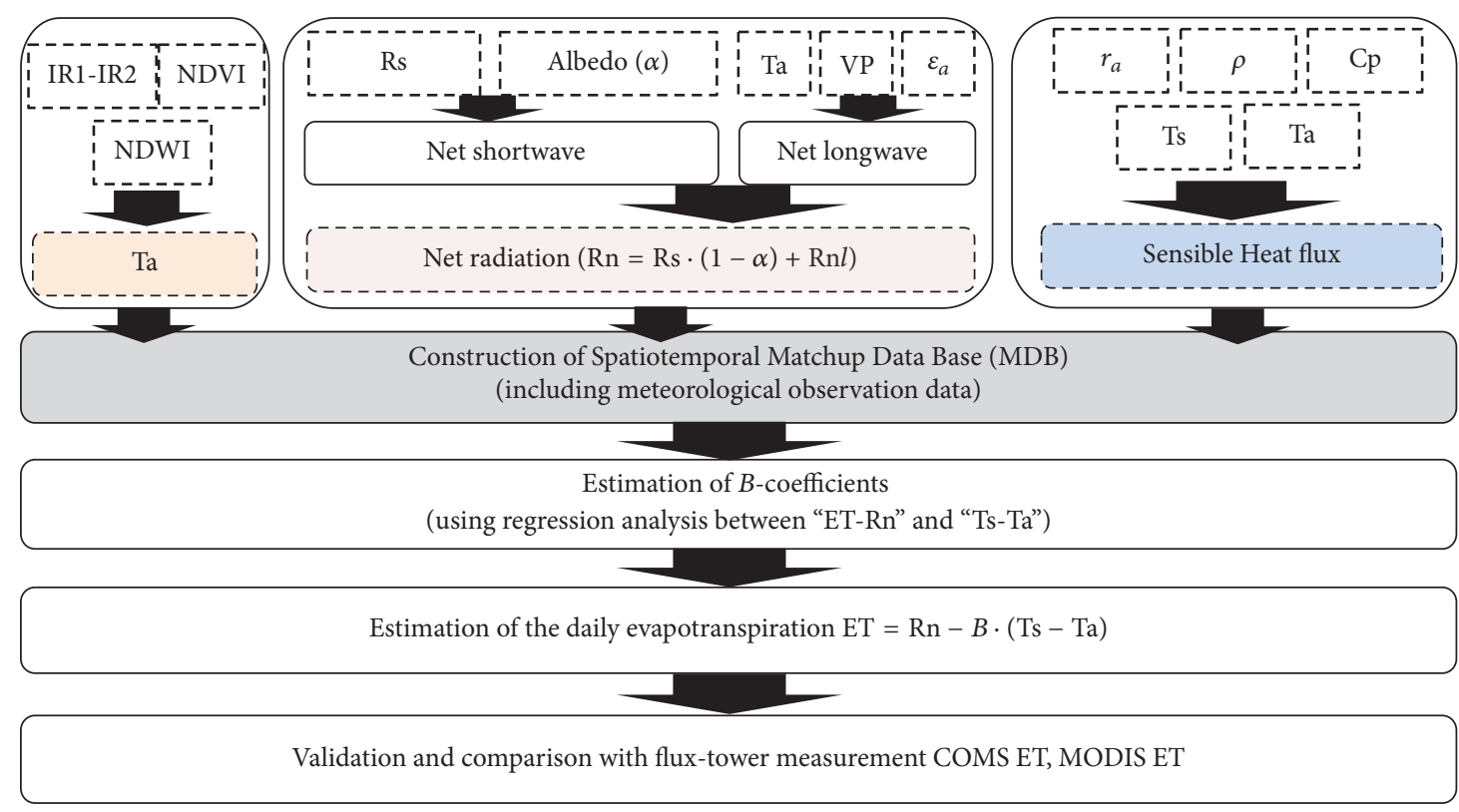

Figure 3: Flowchart of the methodology for estimating the Communication, Ocean and Meteorological Satellite (COMS) daily evapotranspiration (ET).

obtained by converting the latent heat flux observed every $30 \mathrm{~min}$ from the tower using the eddy covariance method to measure directly the vertical fluxes of heat, water vapor, and $\mathrm{CO}_{2}$ between the surface and atmosphere. This was transformed as follows:

$$
\mathrm{ET}=\frac{\mathrm{LE}}{\lambda}
$$

where $\lambda$ is the latent heat of vaporization $(\mathrm{J} / \mathrm{kg})$. This assumes ideal conditions in which the ground is horizontally uniform and flat, there is no sink or source, and the average vertical flux due to turbulence is defined as $F=\overline{\omega^{\prime} c^{\prime}}$ (where $\omega^{\prime}$ is vertical wind speed and $c^{\prime}$ is physical quantity). Wind velocity was measured in the $x, y$, and $z$ directions and $\mathrm{CO}_{2}$, $\mathrm{H}_{2} \mathrm{O}$, and temperature were measured at a rate of $10 \mathrm{~Hz}$ to understand the amount of water movement over time. Table 1 summarizes the information about the flux towers used in this study. The Seolmacheon flux tower (SMK) was in a mixed forest in the middle part of the river basin at an elevation of $293 \mathrm{~m}$. The average height of the trees was $15 \mathrm{~m}$. More than $90 \%$ of the forest is composed of 20-40-year-old coniferous and broadleaf trees. Their ability to replenish water is low due to the shallow topography, and the rocks and gravel are scattered on mountain slopes [54]. The Cheongmicheon flux tower (CFK) was in a rice paddy. The surrounding area was homogeneous and the terrain flat. The $500 \mathrm{~m}$ radius around the tower mostly consisted of rice, and the soil was dominated by sandy loam. The MODIS ET is based on the Penman-Monteith equation, which considers aerodynamic resistance and surface resistance and uses daily meteorological reanalysis data (air pressure, air temperature, humidity, radiation, etc.) and remotely sensed vegetation data (Leaf Area Index, the Fraction of Absorbed Photosynthetically Active Radiation, albedo, and land cover) from MODIS. This algorithm estimates ET and accounts for canopy conductivity, environmental factors (e.g., minimum temperature and difference in saturated water vapor pressure), and evaporation in the soil. The MODIS ET was accumulated at 8-day, monthly, yearly, and $1 \mathrm{~km}$ resolutions.

\section{Methodology}

Figure 3 shows the flowchart for estimating daily ET. First, we estimated the satellite-based air temperature (Section 3.1), daily $\mathrm{Rn}$ using net shortwave and longwave radiation (Section 3.2), and sensible heat flux (Section 3.3). The spatial and temporal resolutions of each input variable from the satellite data (e.g., air temperature, daily Rn, and land surface temperature) and meteorological measurements (e.g., humidity, temperature, and wind speed) were standardized using the matchup database (MDB). Then the $B$-coefficients were estimated by considering the relationship between sensible heat flux and the difference between land surface and air temperatures based on the MDB (Section 3.4). Finally, daily ET was estimated using the $B$-coefficients (Section 3.5).

3.1. Estimation of Daily Air Temperature (Ta). Near-surface air temperature (Ta) is a critical variable for estimating daily ET. Remote-sensing data can be used to estimate $\mathrm{Rn}$ and land surface temperature; however, it is difficult to estimate temperature using satellite data. Generally, Ta values are obtained from meteorological stations $2 \mathrm{~m}$ above the ground, although this can be difficult in mountainous terrain. Due to the limited distribution of meteorological stations, we used an algorithm for satellite-based midday air temperature retrieval over northeast Asia [55]. This algorithm uses COMS Level $1 \mathrm{~B}$ brightness temperature the difference between the IR 1 
TABLE 1: Flux tower measurement information.

\begin{tabular}{|c|c|c|c|c|c|c|}
\hline Flux Site & Location/position & Vegetation Type & Elevation & $\begin{array}{l}\text { Annual mean } \\
\text { precipitation } \\
(\mathrm{mm})\end{array}$ & $\begin{array}{c}\text { Annual mean } \\
\text { Air temperature } \\
\left({ }^{\circ} \mathrm{C}\right)\end{array}$ & $\begin{array}{c}\text { Canopy Height } \\
\text { (m) }\end{array}$ \\
\hline $\begin{array}{l}\text { SMK } \\
\text { (KoFlux } \\
\text { Seolmacheon } \\
\text { Site) }\end{array}$ & $\begin{array}{c}\text { Paju, South } \\
\text { Korea } / 37^{\circ} 56^{\prime} 19^{\prime \prime} \mathrm{N} \text {, } \\
126^{\circ} 57^{\prime} 17^{\prime \prime} \mathrm{E}\end{array}$ & Mixed Forest & $\begin{array}{c}293 \text { m above } \\
\text { sea level }\end{array}$ & $1332 \mathrm{~mm}$ & $11.5^{\circ} \mathrm{C}$ & $15 \mathrm{~m}$ \\
\hline $\begin{array}{l}\text { CFK } \\
\text { (KoFlux } \\
\text { Cheongmicheon } \\
\text { Site) }\end{array}$ & $\begin{array}{c}\text { Yeuju, South } \\
\text { Korea } / 37^{\circ} 9^{\prime} 35^{\prime \prime} \mathrm{N} \\
127^{\circ} 39^{\prime} 10^{\prime \prime} \mathrm{E}\end{array}$ & Rice paddy & $141 \mathrm{~m}$ & $1170 \mathrm{~mm}$ & $11.5^{\circ} \mathrm{C}$ & $1 \mathrm{~m}$ \\
\hline
\end{tabular}

and IR 2 channels, land surface temperature, SPOT/VGT NDWI, and NDVI. Validated to ground measurements, these estimates have an $R^{2}$ value of 0.9401 , a RMSE of $2.89 \mathrm{~K}$, and a bias of $0.49 \mathrm{~K}$ for 13,542 matchup cases points.

3.2. Estimation of Daily Net Radiation ( $R n$ ). Daily $\mathrm{Rn}$ is one of the important parameters of total heat energy for estimating daily ET. It can be estimated using the sum of the difference between the incoming shortwave (Rs) and reflected outgoing shortwave solar radiation $(0.15-5 \mu \mathrm{m})$, and the difference between the downwelling atmospheric and the surface emitted and reflected longwave radiation $(3-100 \mu \mathrm{m})$. The daily $\mathrm{Rn}$ can be expressed as follows:

$$
\mathrm{Rn}=\mathrm{Rn}_{s}+\mathrm{Rn}_{l}=\mathrm{Rs} \cdot(1-\alpha)+\mathrm{Rn}_{l},
$$

where $\mathrm{Rn}_{s}$ is net shortwave radiation $\left(\mathrm{W} / \mathrm{m}^{2}\right), \mathrm{Rn}_{l}$ is net longwave radiation $\left(\mathrm{W} / \mathrm{m}^{2}\right)$, Rs is incoming solar radiation $\left(\mathrm{W} / \mathrm{m}^{2}\right.$ ), and $\alpha$ is surface albedo (dimensionless). $\mathrm{Rn}_{s}$ is the difference between incoming and reflected solar radiation. Rs (i.e., surface solar radiation [insolation]) was estimated based on a physical model [48]. The reflectance of the surface (i.e., surface albedo) was calculated according to a previous study [56] to derive the narrowband-to-broadband albedo as the mean value of normalized reflectance in visible and NIR channels obtained from SPOT/VGT satellites. $\mathrm{Rn}_{l}$ is the difference between outgoing longwave radiation from upwelling surface radiation and incident downwelling atmospheric radiation. It is calculated with the Stefa-Boltzmann law and Brunt equation [57] using a combined $\varepsilon_{\text {bulk }}$ between the air and land surface with maximum and minimum air temperatures:

$$
\mathrm{Rn}_{l}=L \downarrow-L \uparrow=\varepsilon_{\text {bulk }} \cdot \sigma \cdot\left(\frac{T_{\max }^{4}+T_{\min }^{4}}{2}\right),
$$

where $\varepsilon_{\text {bulk }}$ is the net emissivity, $\sigma$ is the Stefan-Boltzmann constant $\left(5.67 \times 10^{-8} \mathrm{~W} / \mathrm{m}^{2} / \mathrm{K}^{4}\right), T_{\max }$ is daily maximum temperature $(\mathrm{K})$, and $T_{\min }$ is daily minimum temperature $(\mathrm{K})$. $\varepsilon_{\text {bulk }}[58,59]$ was calculated as follows:

$$
\varepsilon_{\text {bulk }}=-\left(a \cdot\left(\frac{R_{S}}{R_{\mathrm{SO}}}+b\right) \cdot\left(a_{1}+b_{1} \cdot \sqrt{e_{a}}\right),\right.
$$

where $a$ and $b$ are regression coefficients to correct for cloudiness, $a_{1}$ and $b_{1}$ are regression coefficients to correct for water in the air, $e_{a}$ is actual vapor pressure $(\mathrm{kPa}), R_{\mathrm{so}}$ is clear-sky radiation $\left(\mathrm{W} / \mathrm{m}^{2}\right), R_{s}$ is actual solar radiation $\left(\mathrm{W} / \mathrm{m}^{2}\right)$, and $R_{s} / R_{\mathrm{so}}$ is relative short wave radiation $\left(\mathrm{W} / \mathrm{m}^{2}\right)$. The coefficients $a, b, a_{1}$, and $b_{1}$ can be expressed as follows [60]:

$$
\begin{array}{ll}
a=1.126, & \\
b=-0.07, & \\
& \text { If } \frac{R s}{R s o}>0.7, \\
a=1.017, & \\
b=-0.06, & \text { If } \frac{R s}{R s o} \leq 0.7, \\
a_{1}=0.26+0.1 & \\
& \cdot \exp \left\{-[0.0154 \cdot(30 \cdot m+N-207)]^{2}\right\}, \\
b_{1}= & -0.139,
\end{array}
$$

where $m$ is the number of the month (i.e., 1 for January in the northern hemisphere) and $N$ is day of the month. The daily clear-sky solar radiation uses an exponential model and a cosine model [61] as follows:

$$
\begin{aligned}
R \text { so } & =A^{\prime} \cdot \exp \left[-\left(\frac{\mathrm{JD}-C^{\prime}}{B^{\prime}}\right)^{2}\right], \\
A^{\prime} & =31.25+0.001113 \cdot Z, \\
B^{\prime} & =270-3.008 \cdot L,
\end{aligned}
$$

where $A^{\prime}$ is the peak radiation, $B^{\prime}$ is width of the curve, $C^{\prime}$ is Julian day of the day when the maximum solar radiation occurs (usually around day 172), JD is Julian day, $Z$ is elevation above sea level $(\mathrm{m})$, and $L$ is latitude $\left(^{\circ}\right)$.

3.3. Estimation of Sensible Heat Flux $(H)$. The calculation of sensible heat flux $(H)$ is the most complex component of the surface energy budget. $H$ is the energy emitted from the surface to the atmosphere by the heat transfer processes 
(convection and conduction) due to temperature differences between the surface and the atmosphere [62]. It is estimated following Ohm's Law. $H$ can be calculated by the following bulk aerodynamic resistance equation [63] as follows:

$$
H=\frac{\rho \cdot C_{P} \cdot\left(T_{S}-T_{a}\right)}{r_{a}},
$$

where $H$ is sensible heat flux, $\rho$ is the air density $\left(\mathrm{kg} / \mathrm{m}^{3}\right), C_{P}$ is the specific heat of air at constant pressure $(\mathrm{J} / \mathrm{kg} / \mathrm{K}), T_{a}$ is the air temperature at reference height $(2 \mathrm{~m}), T_{S}$ is the land surface temperature, and $r_{a}$ is the aerodynamic resistance for the heat transport $(\mathrm{s} / \mathrm{m})$. Estimating sensible heat flux using the slope between the surface and air temperatures is complicated and many meteorological parameters (surface/air temperature, relative humidity, wind speed, aerodynamic resistance, and surface roughness length) are required. Therefore, it is difficult to apply to a wide area. In this study, $H$ was simplified as follows:

$$
H=B_{d} \cdot\left(T_{S_{d}}-T_{a_{d}}\right)
$$

where $B_{d}$ is a semiempirical coefficient that varies with land characteristics. It is defined as an "exchange coefficient," which is weighted by $\mathrm{Rn}_{d} / \mathrm{Rn}_{i}$ ratio and shows the instantaneous $\mathrm{Rn}$ contribution at midday for daily radiation on clear days. $\mathrm{Rn}_{d} / \mathrm{Rn}_{i}$ is affected by the change in solar energy depending upon surface conditions and season. It is approximately 0.33 in barren regions [12]. $B_{d}$ is calculated as follows:

$$
\begin{aligned}
B_{d} & \approx \frac{\mathrm{Rn}_{d}}{\mathrm{Rn}_{i}} \cdot \frac{\rho_{m} \cdot C_{p}}{r_{a}} \cdot \frac{1}{\lambda}, \\
\rho_{m} & =\frac{P}{\mathrm{RT}^{\prime}}, \\
P & =101.3-0.01055 \cdot Z, \\
T^{\prime} & =\frac{T}{1-0.378\left(e_{a} / P\right)},
\end{aligned}
$$

where $\lambda$ is the latent heat of vaporization $(\mathrm{kJ} / \mathrm{kg})$, the subscripts $d$ and $i$ represent the values observed at daily and instantaneously at noon, respectively, $P$ is atmospheric pressure $(\mathrm{kPa}), R$ is the specific gas constant for dry air $(0.287 \mathrm{~kJ} / \mathrm{kg} / \mathrm{K}), T^{\prime}$ is the virtual temperature $(\mathrm{K})$, and $e_{a}$ is the actual vapor pressure of the air $(\mathrm{kPa})$. The actual vapor pressure is computed as follows:

$$
e_{a}=e_{d p}^{o}=\mathrm{RH} \cdot e_{\mathrm{db}}^{o}
$$

where $\mathrm{RH}$ is relative humidity (\%) and $e_{\mathrm{db}}^{o}$ is the saturation vapor pressure at dew point temperature $(\mathrm{kPa})$. The latent heat of vaporization is the heat required to change a unit mass of water from a liquid to a vapor at a constant pressure and temperature. In thermodynamic references, it is also known as the enthalpy of vaporization $[64,65]$. Latent heat of vaporization can be estimated using the following linear regression equation [66] as follows:

$$
\lambda=2501-2.3601 \cdot T
$$

where $T$ is air temperature $\left({ }^{\circ} \mathrm{C}\right)$. Aerodynamic resistance, $r_{a}$, is resistance to heat transport between the land surface and the canopy and is affected by many factors including surface roughness (vegetation height and structure), wind speed, and atmospheric stability. Various methods for calculating $r_{a}$ have been developed ranging from extremely elementary (a function of wind speed only) to quite rigorous (accounting for atmospheric stability, wind speed, surface aerodynamic roughness, etc.) [67]. Based on the Monin-Obukhov Similarity Theory for the atmospheric surface layer, the aerodynamic resistance is computed by the following equation [68-71] as follows:

$$
r_{a}=\frac{\ln \left((Z-d) / Z_{0}\right) \ln \left((z-d) / Z_{0} h\right)}{K^{2} \cdot U},
$$

where $K$ is the Karman constant $(=0.41), Z$ is height of the anemometer $(=10 \mathrm{~m}), U$ is wind velocity at height $Z(\mathrm{~m} / \mathrm{s})$, $Z_{0}$ is surface roughness length for momentum transfer (m), $d$ is the zero-plane displacement height (m), and $Z_{0} h$ is surface roughness length for the transfer of heat and vapor $(\mathrm{m})$. Aerodynamic resistance is affected by numerous factors (e.g., surface roughness [vegetation height, vegetation structure], wind speed, and atmospheric stability). Although it is impossible to measure broad vegetation height accurately, it can be estimated using surface roughness as follows:

$$
\begin{aligned}
h & =\frac{Z_{0}}{0.123}, \\
d & =0.67 \cdot h, \\
Z_{0} h & =0.1 \cdot Z_{0},
\end{aligned}
$$

where $h$ is vegetation height $(\mathrm{m})$ and $Z_{0}$ is surface roughness length $(\mathrm{m})$. In this study, $Z_{0}$ for densely vegetated areas was calculated using ECOCLIMAP-DB 1. Areas with low vegetation height were estimated using the vegetation index [53] as follows:

$$
Z_{0}=\exp (-5.5+5.8 \cdot \mathrm{NDVI}) .
$$

The $B$-coefficients change according to the ratio of $\mathrm{Rn}$, the density of wet air, and the aerodynamic resistance (i.e., the change in surface vegetation). $B$-coefficients depend on surface roughness, wind speed, and atmospheric stability.

3.4. Estimation of B-Coefficients. In this study, the $B$ coefficients from [35] were calculated using the spatiotemporal coincidence MDB composed of the ground-based data and satellite data. The $B$-coefficients determined values of the slopes from the regression between ET and Rn and Ts and Ta. There was a negative correlation with $Z_{0}$. Figure 4 shows a linear relationship between ET - Rn and Ts - Ta, which demonstrates their dependence on $Z_{0}$. It also presents the variation in the slopes for $Z_{0}$. The larger the surface roughness, the greater the deviation in $B$ values. The slopes decreased with increasing surface roughness length (Table 2). In this study, the $B$-coefficients were representative of the surface roughness range as follows: $Z_{0}, 0.0207 \mathrm{~m}$ $(0.0048-0.0597 \mathrm{~m}), 0.1044 \mathrm{~m}(0.0602-0.1695 \mathrm{~m}), 0.2110 \mathrm{~m}$ 


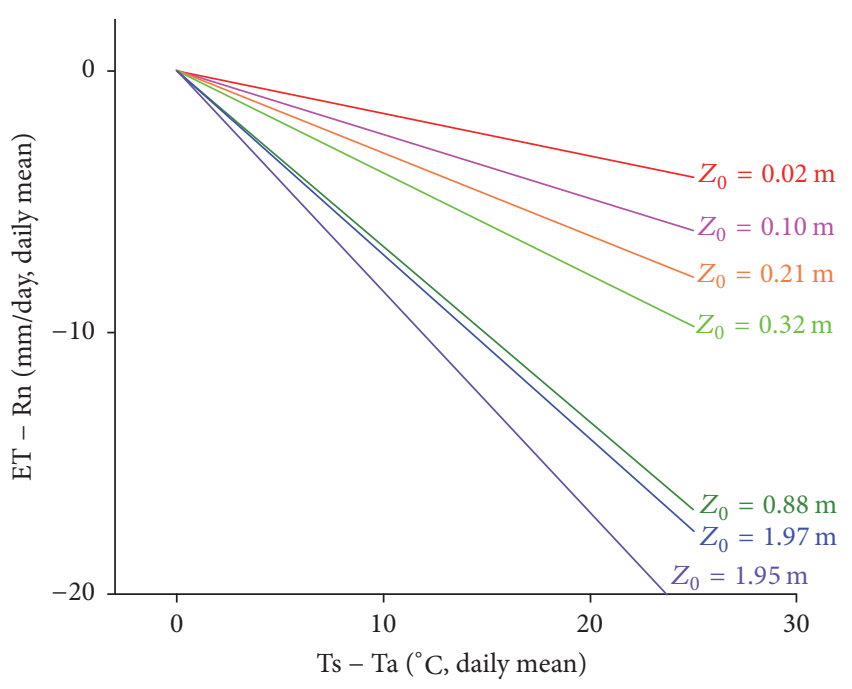

FIgURE 4: The relationship between ET - Rn and Ts - Ta using different surface roughness lengths $\left(Z_{0}\right)$.

TABLE 2: Surface roughness length value according to $B$-coefficients.

\begin{tabular}{lc}
\hline$Z_{0}(\mathrm{~m})$ & $B$-coefficient \\
\hline 0.0207 & 0.1629 \\
0.1044 & 0.2449 \\
0.2110 & 0.3157 \\
0.3200 & 0.3905 \\
0.8800 & 0.6718 \\
0.9700 & 0.7029 \\
1.9500 & 0.8435 \\
\hline
\end{tabular}

(0.1710-0.2486 m), $0.3200 \mathrm{~m}(0.2540-0.4864 \mathrm{~m}), 0.8800 \mathrm{~m}$ $(0.8600-0.9100 \mathrm{~m}), 0.9700 \mathrm{~m}(0.9200-1.000 \mathrm{~m})$, and $1.9500 \mathrm{~m}$ $(1.9200-1.9700 \mathrm{~m})$. The $B$-coefficient model was calculated using representative $B$ values, which were derived using an exponential function model and reflected the surface characteristics of the region:

$$
B=a_{1} \cdot 1-\exp \left(-a_{2} \cdot Z_{0}\right)+a_{3}
$$

where $a_{1}=0.8224, a_{2}=1.3153$, and $a_{3}=0.1381$.

3.5. Estimation of Daily ET. We developed a method for estimating daily ET using the $B$-coefficient model, which reflected vegetation and $Z_{0}$. This algorithm only used satellite data, specifically COMS satellite data:

$$
\begin{aligned}
\mathrm{ET}_{d} & =\mathrm{Rn}_{d}-B \cdot\left(\mathrm{Ts}_{d}-\mathrm{Ta}_{d}\right) \\
B & =0.7705 \cdot\left(1-\exp \left(-1.3153 \cdot Z_{0}\right)\right)+0.1381 .
\end{aligned}
$$

\section{Results}

4.1. Estimation of Daily COMS ET. The daily COMS ET was estimated under clear skies, except in the urban and desert regions. ET was estimated in Korea $\left(33-43^{\circ} \mathrm{N}, 122-132^{\circ} \mathrm{E}\right)$ from 1 April 2011 to the present in real time. The daily
COMS ET estimates only used satellite data (e.g., land surface temperature, air temperature, and solar radiation) from geostationary meteorological satellites. Therefore, these data allow for spatial and temporal monitoring of energy and water cycles over a wide area of Korea. They also reflect vegetation changes and regional characteristics of the land surface using vegetation indices and surface roughness. Figure 5 shows the spatial distribution of the COMS average monthly ET from January to December 2012. Changes in the growth and decline of vegetation from spring to winter on the Korea, which is mainly composed of forests and cultivated areas, were clearly reflected. The spatial and temporal distributions of COMS ET based on the seasonal land characteristics were also clear. In the spring (March, April, and May), the western plains area had many ET values exceeding $0-4 \mathrm{~mm} /$ day. Values over 3-4 mm/day increased during April and May, which was due to the freshwater cultivation of the plains area. In summer (June, July, and August), ET had a maximum of about $6 \mathrm{~mm}$ /day in the eastern part of the Korea. In autumn, ET was 0-4 mm/day in September, $0-3 \mathrm{~mm} /$ day in October, and $0-2 \mathrm{~mm} /$ day in November; this decrease in ET reflected the vegetation decline and harvest that occurs during these months. In winter (December, January, and February), ET was generally $0-2 \mathrm{~mm} /$ day because the vegetation was inactive. The COMS ET is characterized by being impacted on the surface roughness according to the land cover types.

4.2. Validation. To evaluate the accuracy of the daily COMS ET estimates, we compared them with daily flux tower ET measurements and MOD16 data via temporal and spatial analyses.

4.2.1. Validation of Estimated ET with Flux Tower Measurements ET and MODIS ET. In this study, we compared the COMS daily ET with daily flux tower ET measurements and the MOD16 data. The study period was from January to December 2012 and compared COMS data points $(1 \mathrm{~km})$ to the nearest the flux tower measurements in forests and cropland. Figures 6(a) and 6(b) show the results of time series comparisons of COMS daily ET, flux tower ET measurements, and MOD16. Figure 6(a) shows the results of daily ET in a mixed forest; flux tower ET was 0-4 mm/day, COMS daily ET was $0-4.5 \mathrm{~mm} /$ day, and MOD16 was $0-8 \mathrm{~mm} /$ day. COMS ET had similar seasonal patterns to flux tower ET measurements. Conversely, MOD16 was estimated to be $4-8 \mathrm{~mm} /$ day from May to August, which was higher than the flux tower measurements. Figure 6(b) shows the results of daily ET in a rice paddy, where flux tower ET was $0-5.5 \mathrm{~mm} /$ day, COMS daily ET was $0-5.5 \mathrm{~mm} /$ day, and MOD16 was $0-4.5 \mathrm{~mm} /$ day. The COMS daily ET was higher than the flux tower ET measurements by about $1 \mathrm{~mm} /$ day in spring (March-May) when vegetation was growing and in winter (December and January) when vegetation was inactive after harvest. Freshwater cultivation was mainly conducted in rice paddies from April to September; the ET tended to decrease after harvest time in September. Because rice paddies are filled with water during planting, the ET is somewhat higher than that of mixed forests. In addition, in August, flux tower 
January

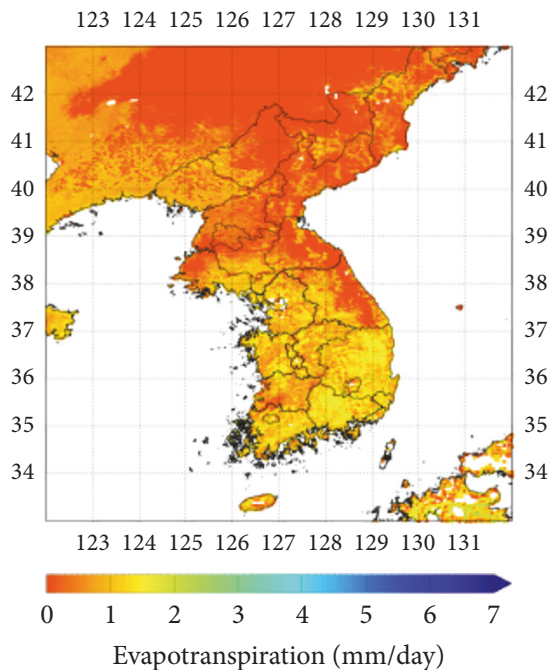

April

$\begin{array}{lllllllll}123 & 124 & 125 & 126 & 127 & 128 & 129 & 130 & 131\end{array}$

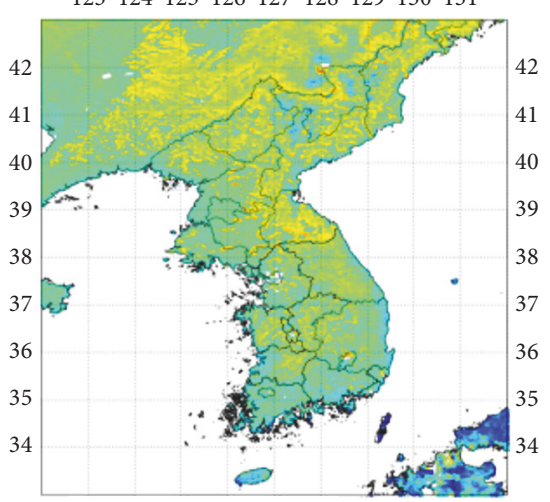

$\begin{array}{lllllllll}123 & 124 & 125 & 126 & 127 & 128 & 129 & 130 & 131\end{array}$



July

$\begin{array}{lllllllll}123 & 124 & 125 & 126 & 127 & 128 & 129 & 130 & 131\end{array}$

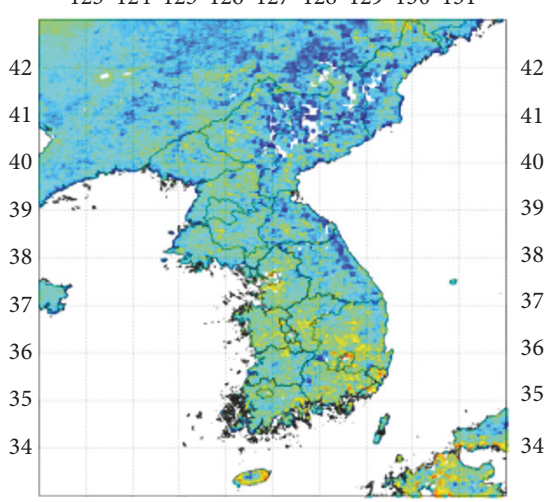

$\begin{array}{lllllllll}123 & 124 & 125 & 126 & 127 & 128 & 129 & 130 & 131\end{array}$

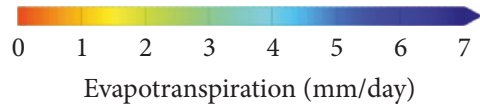

February

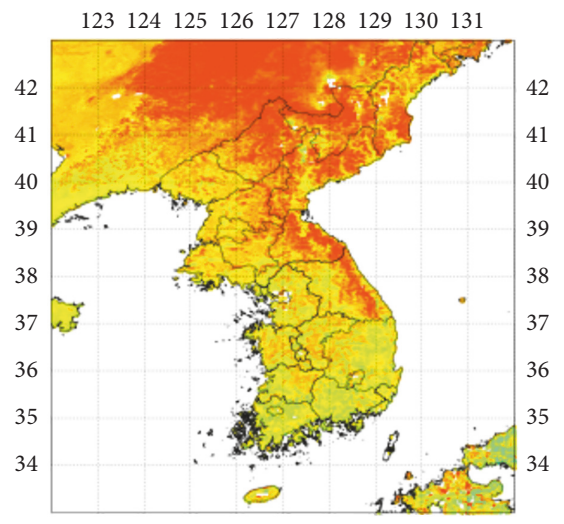

$\begin{array}{lllllllll}123 & 124 & 125 & 126 & 127 & 128 & 129 & 130 & 131\end{array}$

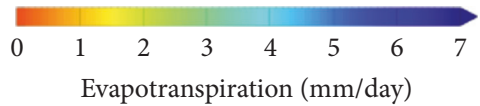

May

$\begin{array}{lllllllll}123 & 124 & 125 & 126 & 127 & 128 & 129 & 130 & 131\end{array}$

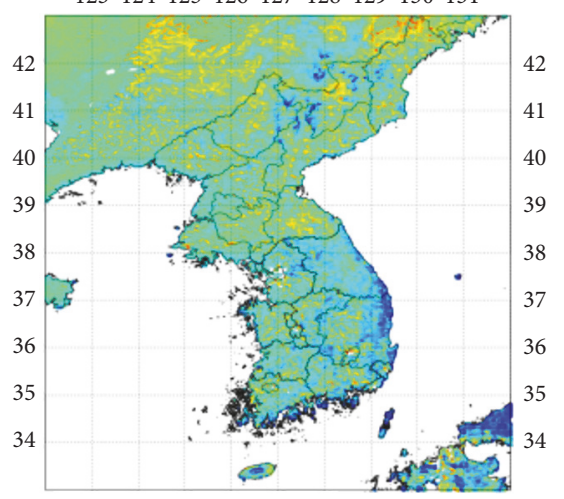

$\begin{array}{lllllllll}123 & 124 & 125 & 126 & 127 & 128 & 129 & 130 & 131\end{array}$

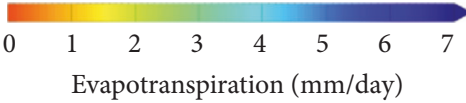

August

$\begin{array}{lllllllll}123 & 124 & 125 & 126 & 127 & 128 & 129 & 130 & 131\end{array}$

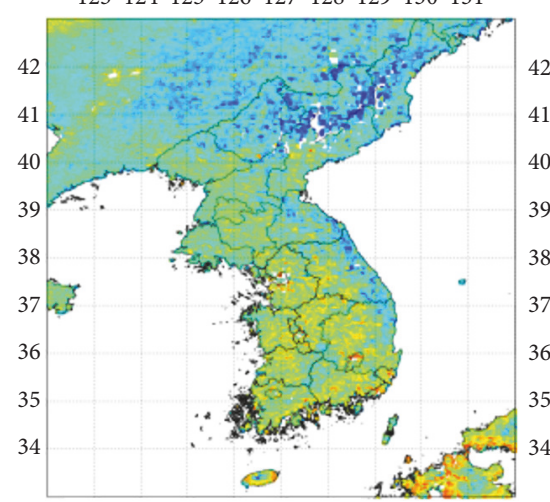

$\begin{array}{lllllllll}123 & 124 & 125 & 126 & 127 & 128 & 129 & 130 & 131\end{array}$

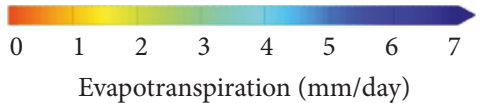

Figure 5: Continued.
March

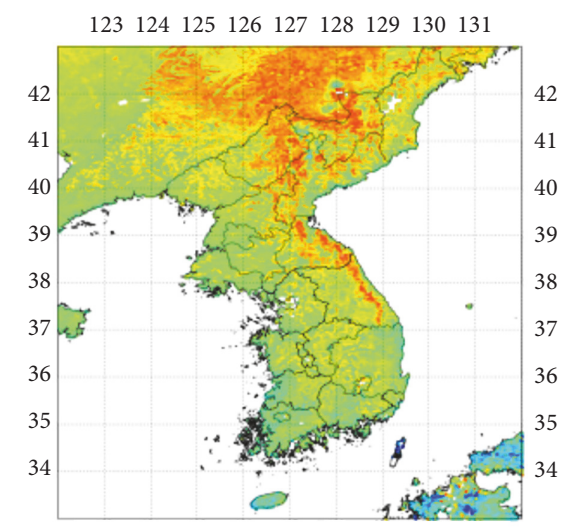

$\begin{array}{lllllllll}123 & 124 & 125 & 126 & 127 & 128 & 129 & 130 & 131\end{array}$

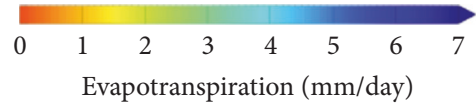

June

$\begin{array}{lllllllll}123 & 124 & 125 & 126 & 127 & 128 & 129 & 130 & 131\end{array}$

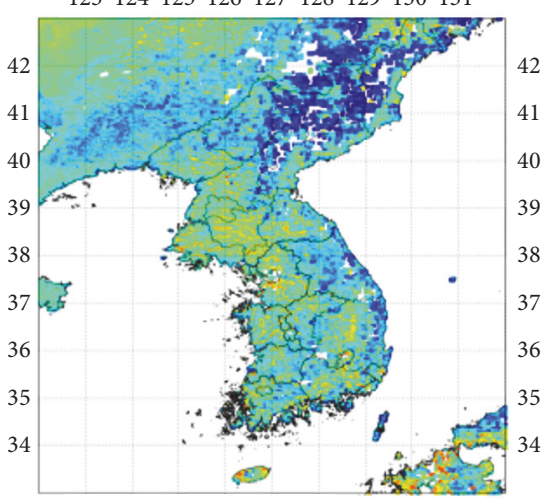

$\begin{array}{lllllllll}123 & 124 & 125 & 126 & 127 & 128 & 129 & 130 & 131\end{array}$

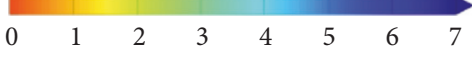

Evapotranspiration (mm/day)

September

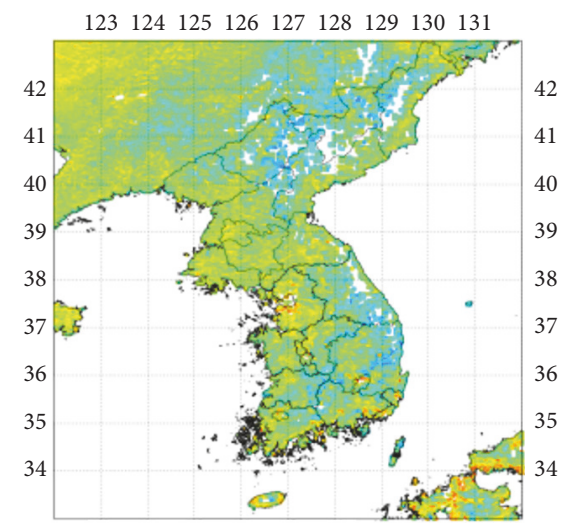

$\begin{array}{lllllllll}123 & 124 & 125 & 126 & 127 & 128 & 129 & 130 & 131\end{array}$

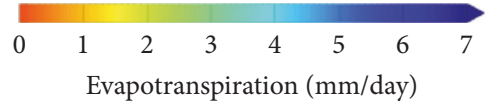

Figure 5: Continued. 
October

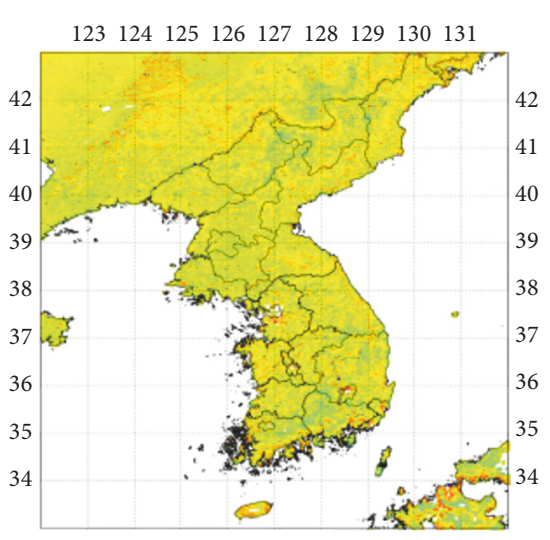

$\begin{array}{lllllllll}123 & 124 & 125 & 126 & 127 & 128 & 129 & 130 & 131\end{array}$

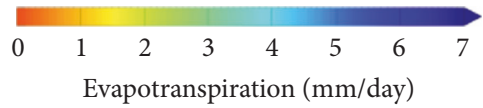

November

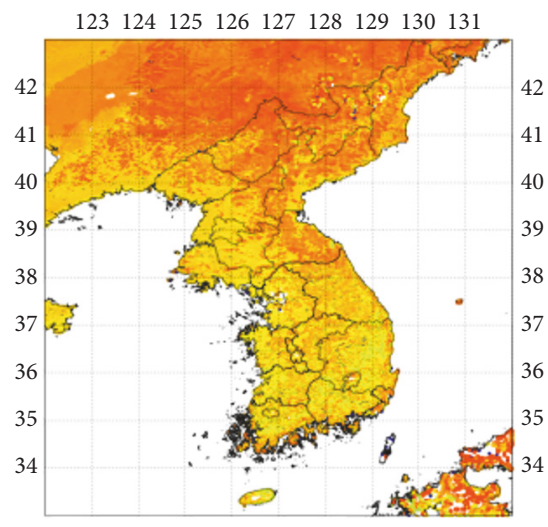

$\begin{array}{lllllllll}123 & 124 & 125 & 126 & 127 & 128 & 129 & 130 & 131\end{array}$

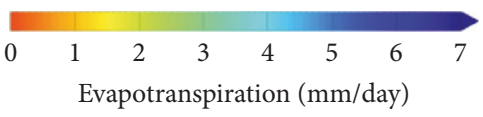

December

$\begin{array}{lllllllll}123 & 124 & 125 & 126 & 127 & 128 & 129 & 130 & 131\end{array}$

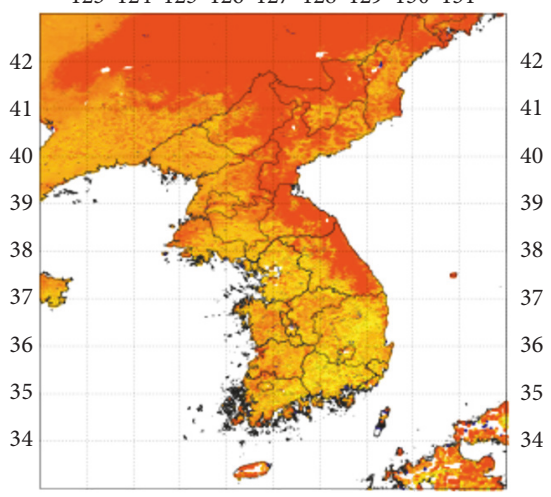

$\begin{array}{lllllllll}123 & 124 & 125 & 126 & 127 & 128 & 129 & 130 & 131\end{array}$

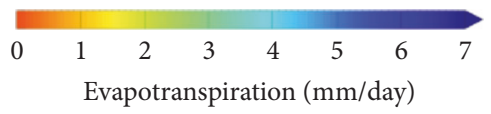

FIGURE 5: Spatial distribution of Communication, Ocean and Meteorological Satellite (COMS) monthly mean evapotranspiration (ET; $\mathrm{mm}$ /day) over Korea in 2012.

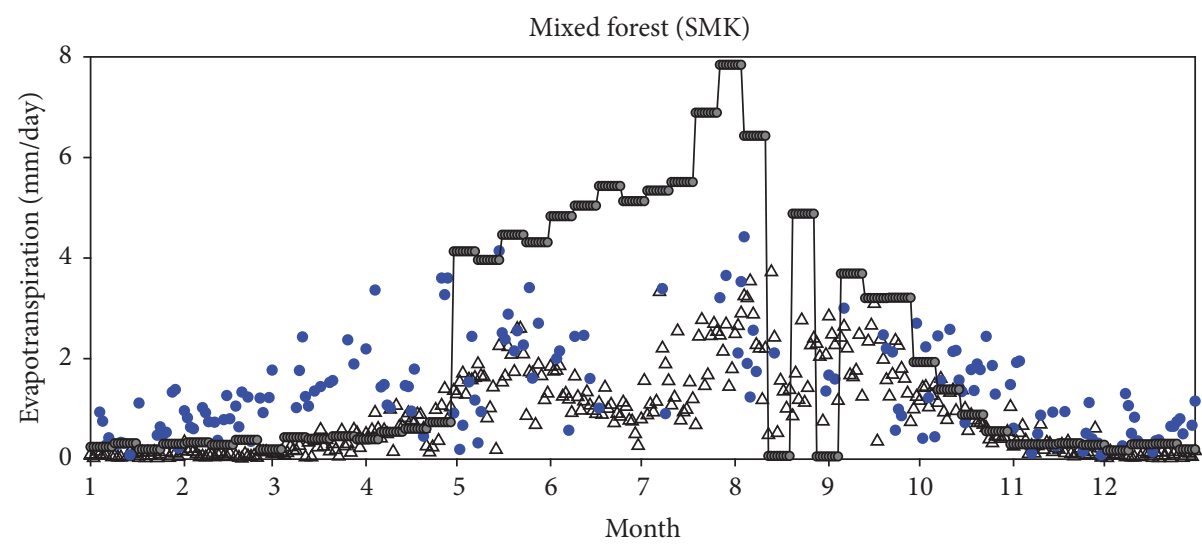

$\Delta \quad$ Flux tower observation ET

- COMS ET

$\multimap$ MODIS ET

(a) SMK (Seolmacheon) flux tower site

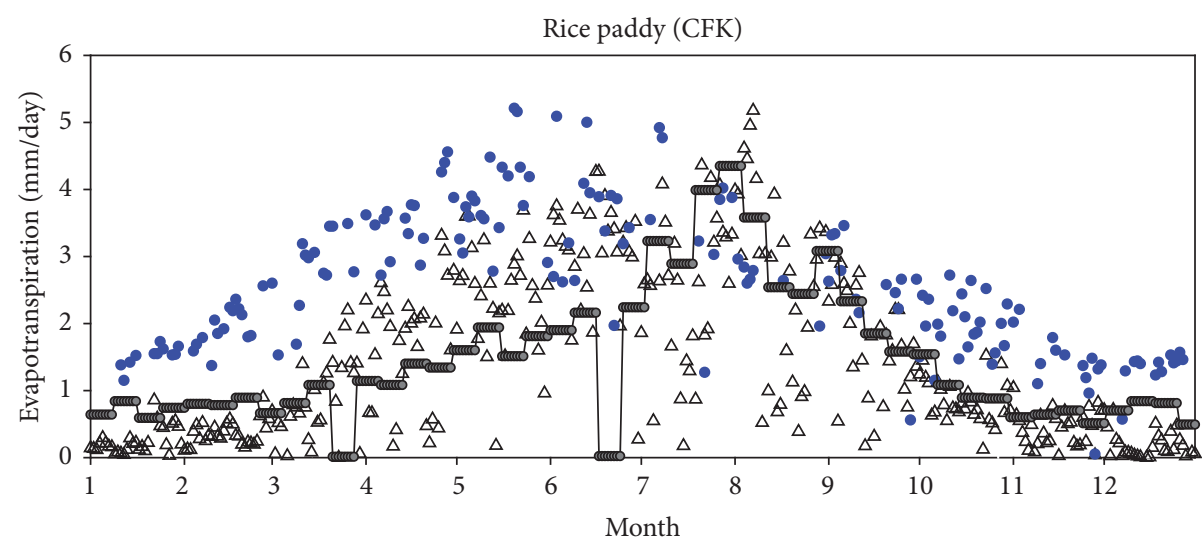

$\Delta \quad$ Flux tower observation ET

- COMS ET

$\multimap$ MODIS ET

(b) CFK (Cheongmicheon) flux tower site

Figure 6: Time series of the Communication, Ocean and Meteorological Satellite (COMS; blue points), MODerate-resolution Imaging Spectrometer (MODIS; gray points and line), and daily flux tower (black triangle) evapotranspiration (ET) measurements during 2012 at flux tower measurements sites in (a) a mixed forest (Seolmacheon, SMK) and (b) a rice paddy (Cheongmicheon, CFK). 


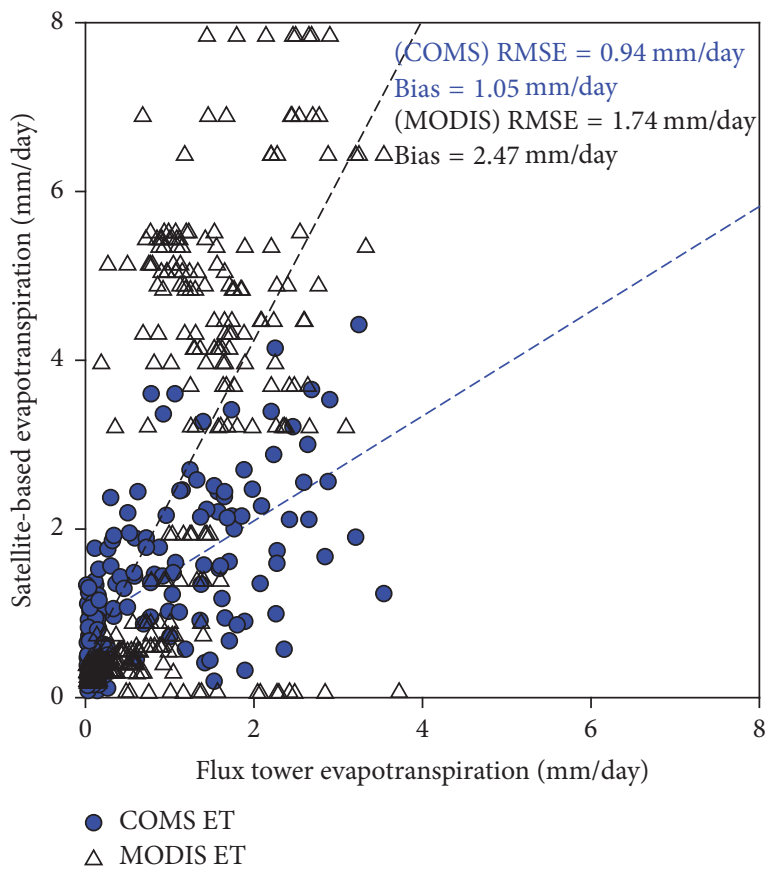

(a) SMK (Seolmacheon) flux tower site

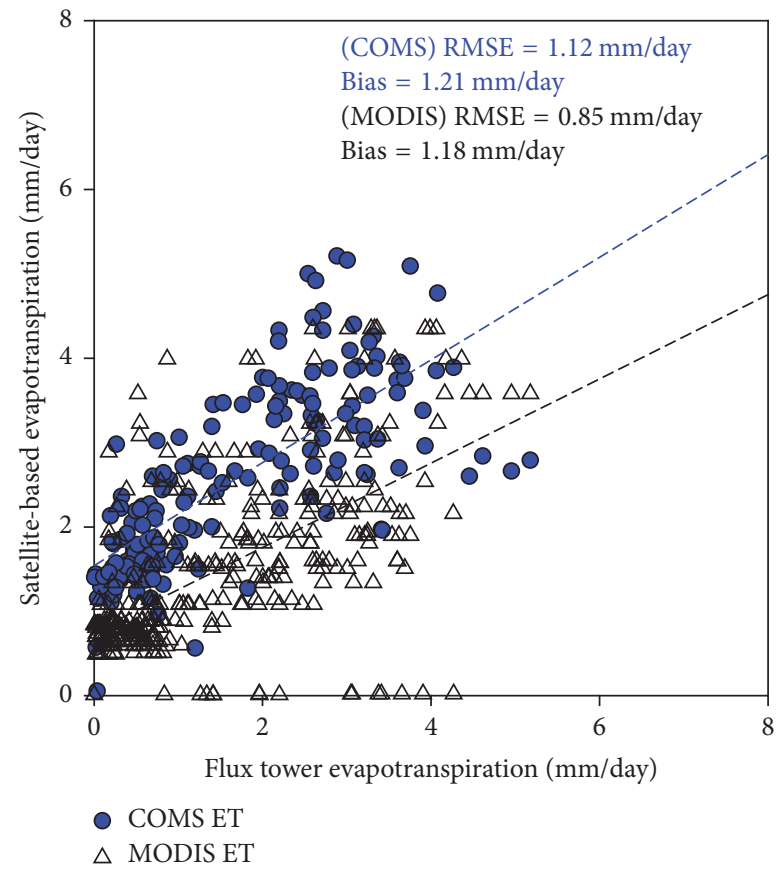

(b) CFK (Cheongmicheon) flux tower site

Figure 7: Comparison between flux tower measurements of daily evapotranspiration (ET; mm/day) and Communication, Ocean and Meteorological Satellite (COMS; blue circles) ET, as well as MODerate-resolution Imaging Spectrometer (MODIS; black triangles) ET over Korea at flux tower sites in (a) a mixed forest (Seolmacheon, SMK) and (b) a rice paddy (Cheongmicheon, CFK).

ET measurements were higher than the COMS daily ET estimates. We assumed that this included a small number of observations affected by clouds, the observation error of instantaneous ET due to remaining water at the surface and being cut off by the evaporation of water by rainfall and vegetation in the summer. Figure 7 shows a scatterplot comparing the daily COMS ET and MOD16 data with flux tower ET measurements from the nearest flux tower measurement sites; the flux tower ET measurements were $0-4 \mathrm{~mm} /$ day, the COMS daily ET estimates were $0-5 \mathrm{~mm} /$ day, and MOD16 values were $0-8 \mathrm{~mm} /$ day. MOD16 values tended to be more than twice as high as the COMS ET estimates. The correlation of flux tower measurements with COMS ET estimates (RMSE: $0.94 \mathrm{~mm} /$ day, bias: $1.05 \mathrm{~mm} /$ day) was lower than that with MOD16 values (RMSE: $1.74 \mathrm{~mm} /$ day, bias: $2.47 \mathrm{~mm} /$ day) by 0.1 . However, the RMSE and bias of COMS ET estimates were better than those of MOD16 by $0.8 \mathrm{~mm} /$ day and $1.42 \mathrm{~mm} /$ day, respectively (Table 3 ). Figure 7 (b) shows that, in the croplands, flux tower ET was 0 $-5.5 \mathrm{~mm} /$ day, COMS daily ET was $0-5.5 \mathrm{~mm} /$ day, and MOD16 was $0-4.5 \mathrm{~mm} /$ day. MOD16 values were slightly lower than the flux tower measurements in agricultural areas with active water supplies because of the lack of regional characteristics. In these areas, the correlation of flux tower measurements with COMS ET estimates (RMSE: $1.12 \mathrm{~mm} /$ day, bias: $1.21 \mathrm{~mm} /$ day) was higher than that with MOD16 values (RMSE: $0.85 \mathrm{~mm} /$ day, bias: $1.18 \mathrm{~mm}$ /day) by 0.12 . However, the RMSE and bias of COMS ET estimates were worse than those of MOD16 by $0.27 \mathrm{~mm} /$ day and $0.02 \mathrm{~mm} /$ day, respectively (Table 4 ).
TABLE 3: Comparisons between daily flux tower evapotranspiration (ET) measurements and Communication, Ocean and Meteorological Satellite (COMS) ET estimates, as well as MODerate-resolution Imaging Spectrometer (MODIS) ET estimates in a mixed forest (SMK) from January to December 2012.

\begin{tabular}{lccccc}
\hline & $R$ & $\begin{array}{c}\text { RMSE } \\
(\mathrm{mm} / \text { day })\end{array}$ & $\begin{array}{c}\text { Bias } \\
(\mathrm{mm} / \text { day })\end{array}$ & $\begin{array}{c}\text { Standard } \\
\text { error } \\
(\mathrm{mm} / \text { day })\end{array}$ & $\begin{array}{c}\text { Number of } \\
\text { observations }\end{array}$ \\
\hline $\begin{array}{l}\text { COMS } \\
\text { ET }\end{array}$ & 0.598 & 0.941 & 1.05 & 0.751 & 125 \\
$\begin{array}{l}\text { MODIS } \\
\text { ET }\end{array}$ & 0.696 & 1.741 & 2.47 & 1.673 & 300 \\
\hline
\end{tabular}

4.2.2. Comparisons of Estimated ET with MODIS ET. Figure 8 shows the spatial distribution of the monthly average COMS and MODIS ET estimates in Korea. Figure 9 shows the probability density function (PDF) of monthly average COMS and MODIS ET estimates in January (winter), April (spring), July (summer), and October (autumn). COMS ET had significant changes in seasonal ET due to vegetation growth and decline throughout Korea (Figure 8(a)). It had a normal distribution function, which ranged from 0 to $5.5 \mathrm{~mm} /$ day over the entire season. In January, the estimated COMS ET was $0-2 \mathrm{~mm} /$ day. In April, when vegetation was growing, the ET range of $2-4 \mathrm{~mm} /$ day accounted for more than $50 \%$ of total values. In July, when rainfall and temperature increased, the mode was about $4 \mathrm{~mm} /$ day with range of $0-5.5 \mathrm{~mm} /$ day. In October, 

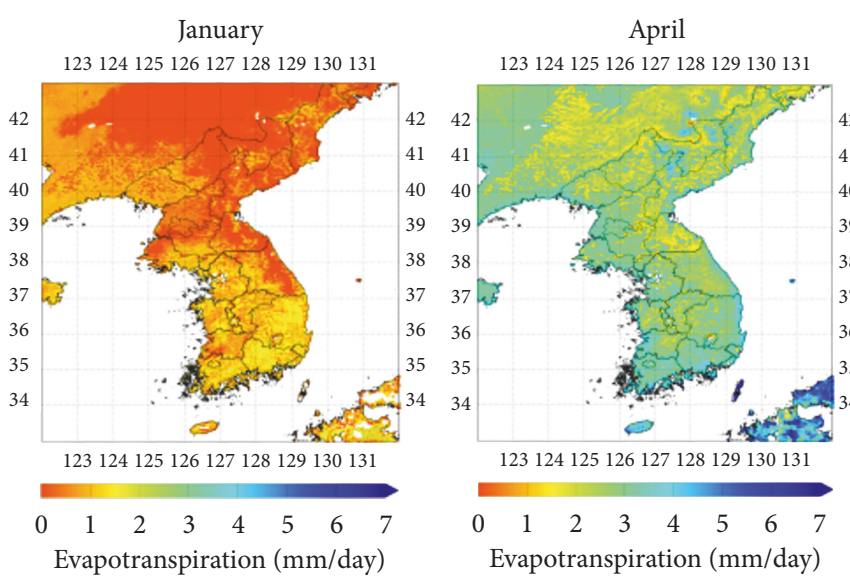

July

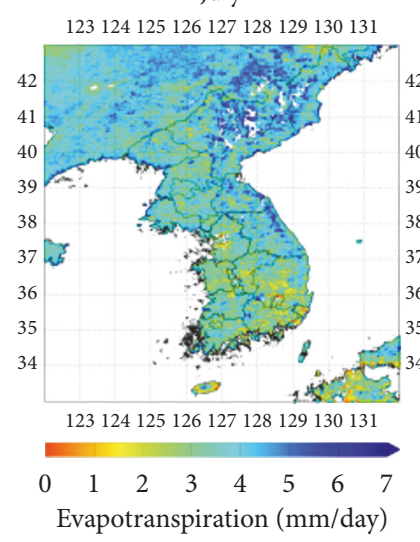

October

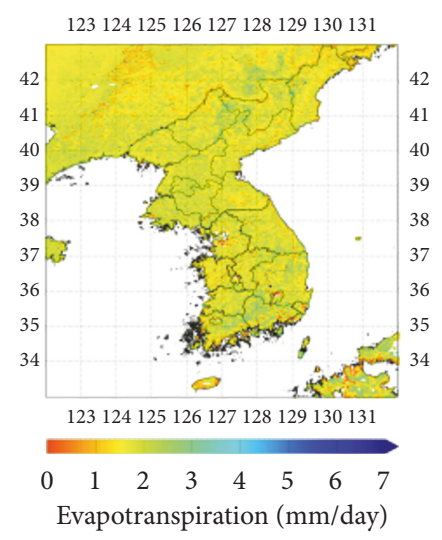

(a) COMS monthly mean evapotranspiration

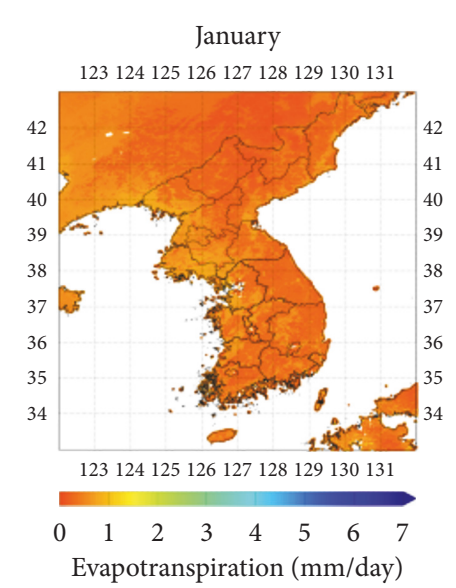

April

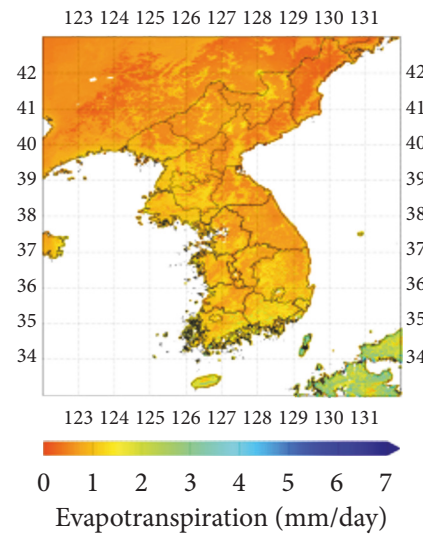

July

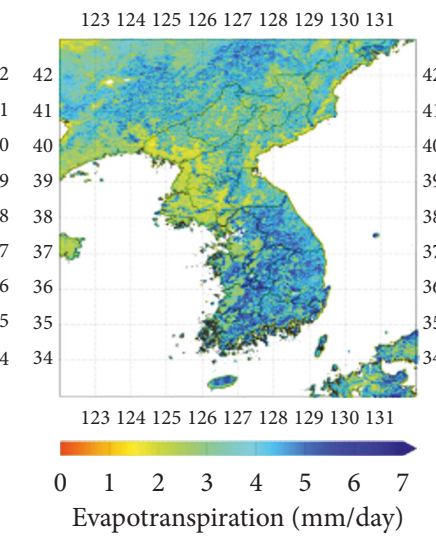

October

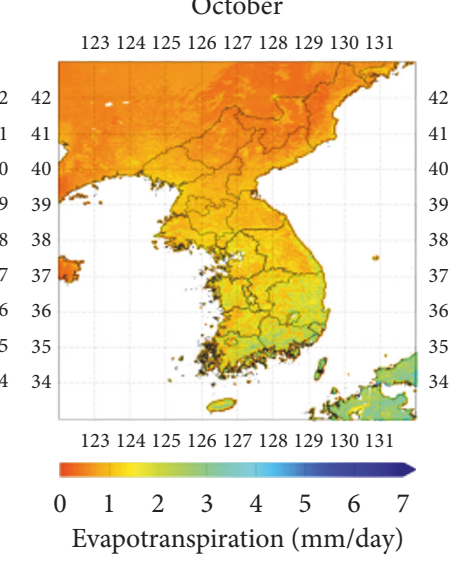

(b) MODIS monthly mean evapotranspiration

FIGURE 8: (a) Communication, Ocean and Meteorological Satellite (COMS) monthly mean actual evapotranspiration (ET) and (b) MODerateresolution Imaging Spectrometer (MODIS) monthly mean ET. Seasonally representative months were selected for this figure: January (winter), April (spring), July (summer), and October (autumn).

TABLE 4: Comparisons between daily flux tower evapotranspiration (ET) measurements and Communication, Ocean and Meteorological Satellite (COMS) ET estimates, as well as MODerate-resolution Imaging Spectrometer (MODIS) ET estimates in a rice paddy (CFK) from January to December 2012.

\begin{tabular}{lccccc}
\hline & $R$ & $\begin{array}{c}\text { RMSE } \\
(\mathrm{mm} / \text { day })\end{array}$ & $\begin{array}{c}\text { Bias } \\
(\mathrm{mm} / \text { day })\end{array}$ & $\begin{array}{c}\text { Standard } \\
\text { error } \\
(\mathrm{mm} / \text { day })\end{array}$ & $\begin{array}{c}\text { Number of } \\
\text { observation }\end{array}$ \\
\hline $\begin{array}{l}\text { COMS } \\
\text { ET }\end{array}$ & 0.737 & 1.122 & 1.205 & 0.722 & 132 \\
$\begin{array}{l}\text { MODIS } \\
\text { ET }\end{array}$ & 0.620 & 0.853 & 1.182 & 0.7943 & 301 \\
\hline
\end{tabular}

when vegetation declined, the ET was $0-3 \mathrm{~mm} /$ day and the $>$ $80 \%$ of estimates were below $2 \mathrm{~mm}$ /day. MODIS ET estimates ranged from 0 to $6 \mathrm{~mm} /$ day (Figure 8(b)). In January, MODIS ET estimates were generally $<1 \mathrm{~mm} /$ day, and over $80-90 \%$ of values were within $0-2 \mathrm{~mm} /$ day except in July (Figure 9 ). In January, about $80 \%$ of values were $0.5 \mathrm{~mm}$ /day, which was the same in the spring. In July, values were still low, with those
$<1 \mathrm{~mm}$ /day accounting for $60 \%$ of the total. In October, when vegetation declined, the values of $0-1 \mathrm{~mm} /$ day accounted for about $70 \%$ of the total.

\section{Summary and Concluding}

Recently, the importance of ET has been recognized in many fields of research, including water management, drought management, and climate change, which require continuous temporal and spatial monitoring. The flux tower ET measurements are disadvantageous because they can be difficult to interpret due to the expected energy imbalance in inhomogeneous and complex terrain. Due to spatial discontinuity of in situ measurements, effective monitoring of terrestrial biogeochemical cycles components at the global scale can be achieved only by satellite observations. To observe ET over a constant time interval and a wide geographic area, various studies are being conducted using satellite observations. Variable parameters (e.g., insolation, land surface temperature, near-surface temperature, albedo, vegetation, and land cover map) based on satellite observation are required to 

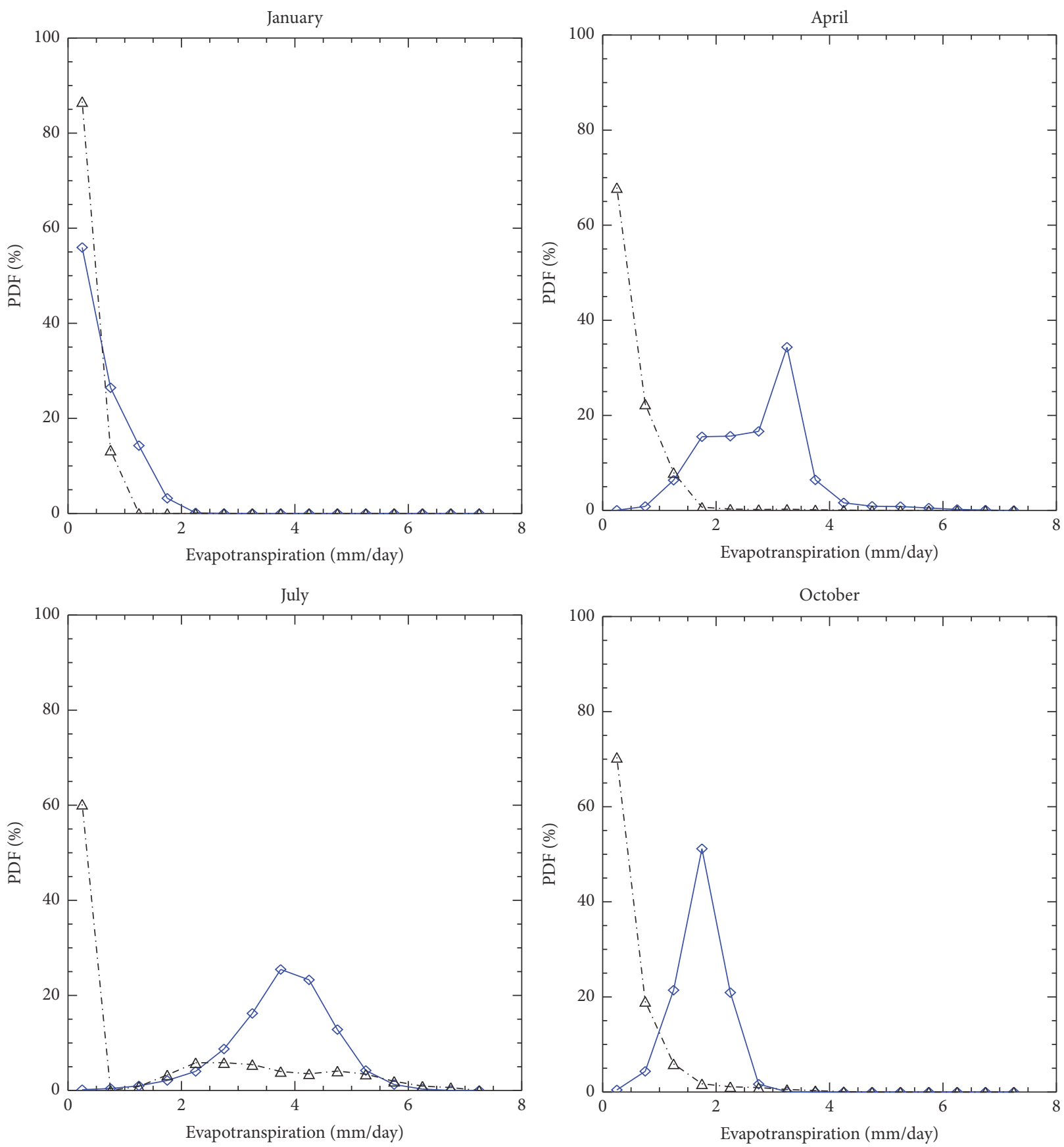

FIGURE 9: Probability density functions (PDF) of monthly mean evapotranspiration from the Communication, Ocean and Meteorological Satellite (COMS; blue line) and MODerate-resolution Imaging Spectrometer (MODIS; the black dash line) over Korea in 2012. Seasonally representative months were selected in this figure: January (winter), April (spring), July (summer), and October (autumn).

estimate the ET of large area. To observe and quantify ET continuously over Korea, we developed an algorithm of simplified daily ET using a combination of geostationary (COMS) and polar-orbiting satellite data (SPOT/VGT). The algorithm for estimating ET reflects vegetation, land surface type, and surface characteristics. The COMS daily ET had a range of $0-6 \mathrm{~mm} /$ day in 1 year; seasonal characteristics were also reflected. To evaluate the accuracy of our estimates, we compared them with the flux tower measurements and
MODIS ET. In the mixed forest, the correlation coefficient $(R)$ between COMS ET and flux tower measurements was about 0.6 , the RMSE was $0.94 \mathrm{~mm} /$ day, and the bias is $1.05 \mathrm{~mm} /$ day, while, in the rice paddy, these values were $0.73,1.12 \mathrm{~mm} / \mathrm{day}$, and $1.21 \mathrm{~mm} /$ day, respectively. Compared to the flux tower measurements, the MODIS ET had a RMSE of $2.47 \mathrm{~mm} /$ day in the forest and $0.85 \mathrm{~mm} /$ day in the cropland, which were higher than those of COMS ET. The values from MODIS ET also tended to be somewhat higher in the forested area 
(range: $0-8 \mathrm{~mm} /$ day) than those from COMS. In addition, the MODIS ET in the flooded cropland ranged from 0 to $4.5 \mathrm{~mm} /$ day, which was lower than the COMS ET and flux tower measurements. The spatial distribution of daily ET estimates tended to change with vegetation growth and decline. However, MODIS ET, which is an 8-day cumulative estimate, was $0-2 \mathrm{~mm} /$ day at the time of vegetation growth and decline (particularly in spring and autumn) and was not sensitive to regional characteristics. This suggests that the results do not fully reflect local characteristics when using GMAO model data as meteorological data.

COMS daily ET using only satellite data (e.g., air temperature, surface temperature, net short- and longwave radiation, and albedo) were relatively accurate. In addition, the ET algorithm simplified the generally complex computational process of sensible heat flux using the $B$-coefficients, which are a function of surface roughness. It had a high periodicity, a temporal resolution of 1 day, and a spatial resolution of $1 \mathrm{~km}$ over a wide area (except urban and desert areas) on clear-sky days. In this study, $B$-coefficient generation model adapts over various land types, which is firstly proposed for northeast Asia region. In many studies, the error of ET estimated using the methods of [35] is about $\pm 1 \mathrm{~mm} /$ day, which is consistent with the error found in this study. This is sufficiently low to provide reliable information for water management [66]. However, the COMS daily ET was estimated and applied differently to the surface roughness based on land cover type. The daily ET was calculated using surface roughness, whose variability can significantly affect estimates. Various other necessary input parameters can also affect ET estimates. That is, input variables can increase the error and uncertainty of the ET values. In the future, we will conduct sensitivity analysis to assess these effects. The cycles and intensities of climate change and droughts are increasing [71]. COMS ET is an important ecological and hydrological parameter expressing the characteristics of the surface and climate through satellite observation. It provides the scientific basis for water management and policies and will play an important role in increasing the application of satellite data. Quantitative observation and monitoring using the spatial distribution of COMS ET over many years not only helps to elucidate climate change in Korea but also provides a means for predicting and investigating the mechanisms of global energy and water cycles, as well as validating hydrological and climate models [72] and numerical model inputs [73]. In the future, highly accurate ET estimates can be used for water resource management (e.g., irrigation for agriculture) and regional evaluation of drought.

\section{Disclosure}

The English language in the document has been checked by at least two native professional editors, both native speakers of English.

\section{Conflicts of Interest}

The authors declare that they have no conflicts of interest.

\section{Acknowledgments}

This study was funded by the KMA/NMSC's R\&D Project, "Technical Development of Satellite Data Application for Operational Weather Service," and the Korea Meteorological Administration Research and Development Program under Grant KMIPA 2015-5041.

\section{References}

[1] C. Lozoya, C. Mendoza, A. Aguilar, A. Román, and R. Castelló, "Sensor-Based Model Driven Control Strategy for Precision Irrigation," Journal of Sensors, vol. 2016, Article ID 9784071, 2016.

[2] D. M. Lawrence, P. E. Thornton, K. W. Oleson, and G. B. Bonan, "The partitioning of evapotranspiration into transpiration, soil evaporation, and canopy evaporation in a GCM: impacts on land-atmosphere interaction," Journal of Hydrometeorology, vol. 8, no. 4, pp. 862-880, 2007.

[3] M. Jung, M. Reichstein, P. Ciais et al., "Recent decline in the global land evapotranspiration trend due to limited moisture supply," Nature, vol. 467, no. 7318, pp. 951-954, 2010.

[4] J. Peng, M. Borsche, Y. Liu, and A. Loew, "How representative are instantaneous evaporative fraction measurements of daytime fluxes?" Hydrology and Earth System Sciences, vol. 17, no. 10, pp. 3913-3919, 2013.

[5] K. C. Wang and R. E. Dickinson, "A review of global terrestrial evapotranspiration: observation, modeling, climatology, and climatic variability," Reviews of Geophysics, vol. 50, no. 2, 2012.

[6] A. Ershadi, M. F. McCabe, J. P. Evans, N. W. Chaney, and E. F. Wood, "Multi-site evaluation of terrestrial evaporation models using FLUXNET data," Agricultural and Forest Meteorology, vol. 187, pp. 46-61, 2014.

[7] A. J. Dolman, D. G. Miralles, and R. A. M. de Jeu, "Fifty years since Monteith's 1965 seminal paper: The emergence of global ecohydrology," Ecohydrology, vol. 7, no. 3, pp. 897-902, 2014.

[8] Q. Mu, M. Zhao, and S. W. Running, "MODIS Global Terrestrial Evapotranspiration (ET) Product (NASA MOD16A2/A3)," Algorithm Theoretical Basis Document, Collection 5, 2013.

[9] Z. Su, "The Surface Energy Balance System (SEBS) for estimation of turbulent heat fluxes," Hydrology and Earth System Sciences, vol. 6, no. 1, pp. 85-99, 2002.

[10] R. Rivas and V. Caselles, "A simplified equation to estimate spatial reference evaporation from remote sensing-based surface temperature and local meteorological data," Remote Sensing of Environment, vol. 93, no. 1-2, pp. 68-76, 2004.

[11] C. Abdelghani, J. C. B. Hoedjes, J.-C. Rodriquez et al., "Using remotely sensed data to estimate area-averaged daily surface fluxes over a semi-arid mixed agricultural land," Agricultural and Forest Meteorology, vol. 148, no. 3, pp. 330-342, 2008.

[12] B. Seguin and B. Itier, "Using midday surface temperature to estimate daily evaporation from satellite thermal IR data," International Journal of Remote Sensing, vol. 4, no. 2, pp. 371383, 1983.

[13] D. L. Spittlehouse and T. A. Black, "Evaluation of the bowen ratio/energy balance method for determining forest evapotranspiration," Atmosphere - Ocean, vol. 18, no. 2, pp. 98-116, 1980.

[14] A. L. Ruhoff, A. R. Paz, W. Collischonn, L. E. Aragao, H. R. Rocha, and Y. S. Malhi, "A MODIS-Based Energy Balance to Estimate Evapotranspiration for Clear-Sky Days in Brazilian Tropical Savannas," Remote Sensing, vol. 4, no. 12, pp. 703-725, 2012. 
[15] J. M. Sánchez, V. Caselles, R. Niclós, E. Valor, C. Coll, and T. Laurila, "Evaluation of the B-method for determining actual evapotranspiration in a boreal forest from MODIS data," International Journal of Remote Sensing, vol. 28, no. 6, pp. 1231-1250, 2007.

[16] E. P. Glenn, A. R. Huete, P. L. Nagler, and S. G. Nelson, "Relationship between remotely-sensed vegetation indices, canopy attributes and plant physiological processes: What vegetation indices can and cannot tell us about the landscape," Sensors, vol. 8, no. 4, pp. 2136-2160, 2008.

[17] E. P. Glenn, K. Morino, K. Didan et al., "Scaling sap flux measurements of grazed and ungrazed shrub communities with fine and coarse-resolution remote sensing," Ecohydrology, vol. 1, no. 4, pp. 316-329, 2008.

[18] P. L. Nagler, J. Cleverly, E. Glenn, D. Lampkin, A. Huete, and Z. Wan, "Predicting riparian evapotranspiration from MODIS vegetation indices and meteorological data," Remote Sensing of Environment, vol. 94, no. 1, pp. 17-30, 2005.

[19] W. G. M. Bastiaanssen, M. Menenti, R. A. Feddes, and A. A. M. Holtslag, "A remote sensing surface energy balance algorithm for land (SEBAL): 1. Formulation," Journal of Hydrology, vol. 212, no. 1-4, pp. 198-212, 1998.

[20] P. H. Gowda, J. Chävez, T. A. Howell, T. H. Marek, and L. L. New, "Surface energy balance based evapotranspiration mapping in the Texas high plains," Sensors, vol. 8, no. 8, pp. 5186-5201, 2008.

[21] K. Nishida, R. R. Nemani, J. M. Glassy, and S. W. Running, "Development of an evapotranspiration index from Aqua/ MODIS for monitoring surface moisture status," IEEE Transactions on Geoscience and Remote Sensing, vol. 41, no. 2, pp. 493501, 2003.

[22] J. Overgaard, D. Rosbjerg, and M. B. Butts, "Land-surface modelling in hydrological perspective - A review," Biogeosciences, vol. 3, no. 2, pp. 229-241, 2006.

[23] R. G. Allen, M. Tasumi, A. Morse et al., "Satellite-based energy balance for mapping evapotranspiration with internalized calibration (METRIC) - applications," Journal of Irrigation and Drainage Engineering, vol. 133, no. 4, pp. 395-406, 2007.

[24] W. Kustas and M. Anderson, "Advances in thermal infrared remote sensing for land surface modeling," Agricultural and Forest Meteorology, vol. 149, no. 12, pp. 2071-2081, 2009.

[25] Y. Lee and S. Kim, "The Modified SEBAL for Mapping Daily Spatial Evapotranspiration of South Korea Using Three Flux Towers and Terra MODIS Data," Remote Sensing, vol. 8, no. 12, article 983, 2016.

[26] A. Tsouni, C. Kontoes, D. Koutsoyiannis, P. Elias, and N. Mamassis, "Estimation of actual evapotranspiration by remote sensing: Application in Thessaly plain, Greece," Sensors, vol. 8, no. 6 , pp. 3586-3600, 2008.

[27] H. A. Cleugh, R. Leuning, Q. Mu, and S. W. Running, "Regional evaporation estimates from flux tower and MODIS satellite data, Remote Sensing of Environment, vol. 106, no. 3, pp. 285304, 2007.

[28] Q. Mu, M. Zhao, and S. W. Running, "Improvements to a MODIS global terrestrial evapotranspiration algorithm," Remote Sensing of Environment, vol. 115, no. 8, pp. 1781-1800, 2011.

[29] K. Jang, S. Kang, J. Kim et al., "Mapping evapotranspiration using MODIS and MM5 Four-Dimensional Data Assimilation," Remote Sensing of Environment, vol. 114, no. 3, pp. 657-673, 2010.

[30] C. H. Priestley and R. J. Taylor, "On the Assessment of Surface Heat Flux and Evaporation Using Large-Scale Parameters," Monthly Weather Review, vol. 100, no. 2, pp. 81-92, 1972.
[31] V. Venturini, S. Islam, and L. Rodriguez, "Estimation of evaporative fraction and evapotranspiration from MODIS products using a complementary based model," Remote Sensing of Environment, vol. 112, no. 1, pp. 132-141, 2008.

[32] J. Baik and M. Choi, "Evaluation of geostationary satellite (COMS) based Priestley-Taylor evapotranspiration," Agricultural Water Management, vol. 159, pp. 77-91, 2015.

[33] N. Ghilain, A. Arboleda, and F. Gellens-Meulenberghs, "Evapotranspiration modelling at large scale using near-real time MSG SEVIRI derived data," Hydrology and Earth System Sciences, vol. 15, no. 3, pp. 771-786, 2011.

[34] LSA-SAF: Product User Manual (PUM) Evapotranspiration (ET), “PUM_METv2.5," http://landsaf.meteo.pt/, 2015.

[35] R. D. Jackson, R. J. Reginato, and S. B. Idso, "Wheat canopy temperature: A practical tool for evaluating water requirements," Water Resources Research, vol. 13, no. 3, pp. 651-656, 1977.

[36] T. N. Carlson and M. J. Buffum, "On estimating total daily evapotranspiration from remote surface temperature measurements," Remote Sensing of Environment, vol. 29, no. 2, pp. 197$207,1989$.

[37] T. N. Carlson, W. J. Capehart, and R. R. Gillies, "A new look at the simplified method for remote sensing of daily evapotranspiration," Remote Sensing of Environment, vol. 54, no. 2, pp. 161167, 1995.

[38] R. R. Gillies, W. P. Kustas, and K. S. Humes, "A verification of the 'triangle' method for obtaining surface soil water content energy fluxes from remote measurements of the normalized difference vegetation index (NDVI) and surface radiant temperature," International Journal of Remote Sensing, vol. 18, no. 15, pp. 31453166, 1997.

[39] A. Vidal and A. Perrier, "Analysis of a simplified relation for estimating daily evapotranspiration from satellite thermal IR data," International Journal of Remote Sensing, vol. 10, no. 8, pp. 1327-1337, 1989.

[40] J.-P. Lagouarde and K. J. McAneney, "Daily sensible heat flux estimation from a single measurement of surface temperature and maximum air temperature," Boundary-Layer Meteorology, vol. 59, no. 4, pp. 341-362, 1992.

[41] D. Courault, P. Clastre, J. Guinot, and B. Seguin, "Analyse des sécheresses de 1988 à 1990 en France à partir de l'analyse combinée de données satellitaires NOAA-AVHRR et d'un modèle agrométéorologique," Agronomie, vol. 14, no. 1, pp. 41-56, 1994.

[42] E. Assad, B. Seguin, Y. Kerr, J. P. Fréteaud, and J. P. Lagouarde, "The possible applications of Meteosat for monitoring the rain season in the Sahel zone: The case of Senegal," Advances in Space Research, vol. 7, no. 3, pp. 67-71, 1987.

[43] A. Rosema, "Comparison of meteosat-based rainfall and evapotranspiration mapping in the sahel region," International Journal of Remote Sensing, vol. 11, no. 12, pp. 2299-2309, 1990.

[44] A. Brasa Ramos, F. Martín De Santa Olalla, and V. Caselles, "Maximum and actual evapotranspiration for barley (Hordeum vulgare L.) through NOAA satellite images in Castilla-La Mancha, Spain," Journal of Agricultural Engineering Research, vol. 63, no. 4, pp. 283-294, 1996.

[45] K.-S. Han, A. A. Viau, and F. Anctil, "Hourly evapotranspiration derived from NOAA-AVHRR visible and GOES-IMAGER thermal infrared data," International Journal of Remote Sensing, vol. 31, no. 11, pp. 2817-2836, 2010.

[46] R. G. Allen, L. S. Pereira, D. Raes, and M. Smith, "Crop evapotranspiration - Guidelines for computing crop water requirements," FAO Irrigation and Drainage paper 56, FAO, Rome, vol. 300, no. 9, 1998. 
[47] H. Kawamura, S. Tanahashi, and T. Takahashi, "Estimation of insolation over the Pacific Ocean off the Sanriku Coast," Journal of Oceanography, vol. 54, no. 5, pp. 457-464, 1998.

[48] S.-I. Kim, D.-S. Ahn, K.-S. Han, and J.-M. Yeom, "Improved Vegetation Profiles with GOCI Imagery Using Optimized BRDF Composite," Journal of Sensors, vol. 2016, Article ID 7165326, 2016.

[49] J. M. Yeom, K. S. Han, and Y. S. Kim, "Identification of contaminated pixels in 10-day NDVI image," in Proceedings of the Korean Society of Remote Sensing Spring Conference, vol. 12, pp. 113-116, 2006.

[50] B.-C. Gao, "NDWI-a normalized difference water index for remote sensing of vegetation liquid water from space," Remote Sensing of Environment, vol. 58, no. 3, pp. 257-266, 1996.

[51] V. Masson, J.-L. Champeaux, F. Chauvin, C. Meriguet, and R. Lacaze, "A global database of land surface parameters at 1-km resolution in meteorological and climate models," Journal of Climate, vol. 16, no. 9, pp. 1261-1282, 2003.

[52] J.-L. Champeaux, K.-S. Han, D. Arcos, F. Habets, and V. Masson, "Ecoclimap2: A new approach at global and European scale for ecosystems mapping and associated surface parameters database using SPOT/VEGETATION data - First results," in Proceedings of the 2004 IEEE International Geoscience and Remote Sensing Symposium Proceedings: Science for Society: Exploring and Managing a Changing Planet. IGARSS 2004, pp. 2046-2049, Anchorage, Alaska, USA, September 2004.

[53] R. K. Gupta, T. S. Prasad, and D. Vijayan, "Estimation of roughness length and sensible heat flux from wiFS and NOAA AVHRR data," Advances in Space Research, vol. 29, no. 1, pp. 3338, 2002 .

[54] H. Kwon, J. Lee, Y. Lee, J. Lee, S. Jung, and J. Kim, "Seasonal Variations of Evapotranspiration Observed in a Mixed forest in the Seolmacheon Catchment," Korean Journal of Agricultural and Forest Meteorology, vol. 11, no. 1, pp. 39-47, 2009.

[55] J.-H. Ryu, K.-S. Han, J. Cho et al., "Estimating midday nearsurface air temperature by weighted consideration of surface and atmospheric moisture conditions using COMS and SPOT satellite data," International Journal of Remote Sensing, vol. 36, no. 13, pp. 3503-3518, 2015.

[56] R. W. Saunders, "The determination of broad band surface albedo from AVHRR visible and near-infrared radiances," International Journal of Remote Sensing, vol. 11, no. 1, pp. 49-67, 1990.

[57] D. Brunt, "Notes on radiation in the atmosphere," Quarterly Journal of the Royal Meteorological Society, vol. 58, no. 247, pp. 389-420, 1932.

[58] H. Bjornlund, "Water governance for sustainable irrigation: the role of civil society," in Proceedings of the Sustainable Irrigation 2014, pp. 211-222, Poznan, Poland, June 2014.

[59] R. D. Burman, R. H. Cuenca, and A. Weiss, "Techniques for estimating irrigation water requirements," Advances in Irrigation, 1983.

[60] J. L. Wright, "New evapotranspiration crop coefficients," Journal of the Irrigation and Drainage Division, vol. 108, no. IR2, pp. 5774, 1982, Proceeding of the American Society of Civil Engineers.

[61] D. F. Heermann, G. J. Harrington, and K. M. Stahl, "Empirical estimation of daily clear sky solar radiation.," Journal of Climate \& Applied Meteorology, vol. 24, no. 3, pp. 206-214, 1985.

[62] A. S. Monin and A. M. Obukhov, "Basic laws of turbulent mixing in the surface layer of the atmosphere," Contributions of the Geophysical Institute of the Slovak Academy of Sciences, vol. 24, no. 151, pp. 163-187, 1954.
[63] J. L. Monteith, Principles of Environmental Physics, Edward Amold, London, UK.

[64] H. F. Silver and J. E. Nydahl, Introduction to Engineering Thermodynamics, West Publishing Company, St Paul, Minn, USA, 1977.

[65] G. J. Van Wylen and R. E. Sonntag, Fundamentals of Classical Thermodynamics, John Wiley \& Sons, Ltd, New York, NY, USA, 1985.

[66] A. R. Harris and I. M. Mason, "An extension to the split-window technique giving improved atmospheric correction and total water vapour," International Journal of Remote Sensing, vol. 13, no. 5, pp. 881-892, 1992.

[67] Z. Li, R. Tang, Z. Wan et al., "A review of current methodologies for regional evapotranspiration estimation from remotely sensed data," Sensors, vol. 9, no. 5, pp. 3801-3853, 2009.

[68] M. E. Jensen and R. G. Allen, Evapotranspiration and Irrigation Water Requirements, American Society of Civil Engineers, Reston, Va, USA, 1990.

[69] R. G. Allen, "A penman for all seasons," Journal of Irrigation and Drainage Engineering, vol. 112, no. 4, pp. 348-368, 1986.

[70] R. G. Allen, M. E. Jensen, J. L. Wright, and R. D. Burman, "Operational estimates of reference evapotranspiration," Agronomy Journal, vol. 81, no. 4, pp. 650-662, 1989.

[71] M. Zhao and S. W. Running, "Drought-induced reduction in global terrestrial net primary production from 2000 through 2009," Science, vol. 329, no. 5994, pp. 940-943, 2010.

[72] D. Michel, C. Jiménez, D. G. Miralles et al., "The WACMOSET project - Part 1: Tower-scale evaluation of four remotesensing-based evapotranspiration algorithms," Hydrology and Earth System Sciences, vol. 20, no. 2, pp. 803-822, 2016.

[73] B. Mueller, S. I. Seneviratne, C. Jimenez et al., "Evaluation of global observations-based evapotranspiration datasets and IPCC AR4 simulations," Geophysical Research Letters, vol. 38, no. $6,2011$. 


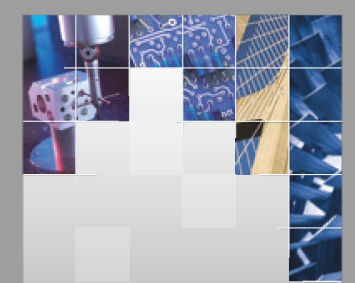

\section{Enfincering}
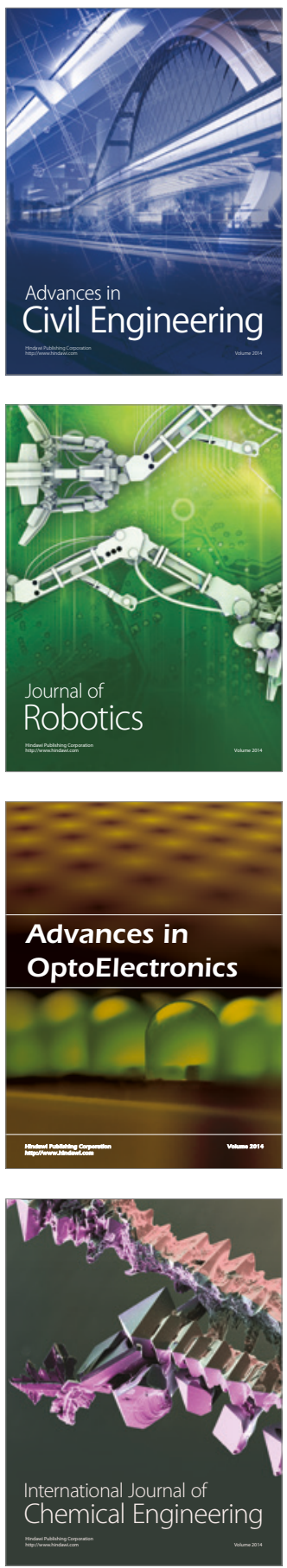

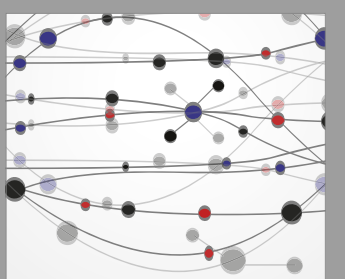

The Scientific World Journal

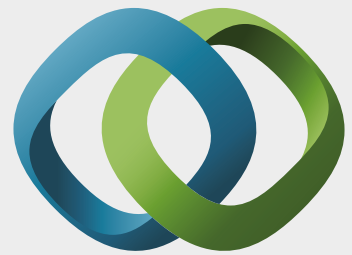

\section{Hindawi}

Submit your manuscripts at

https://www.hindawi.com
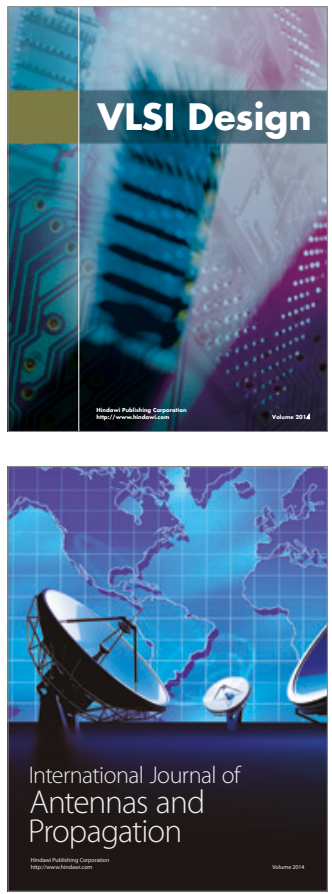

\section{Rotating}

Machinery
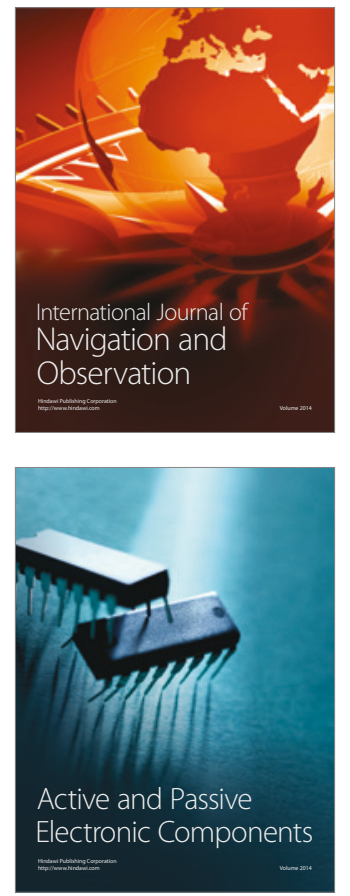
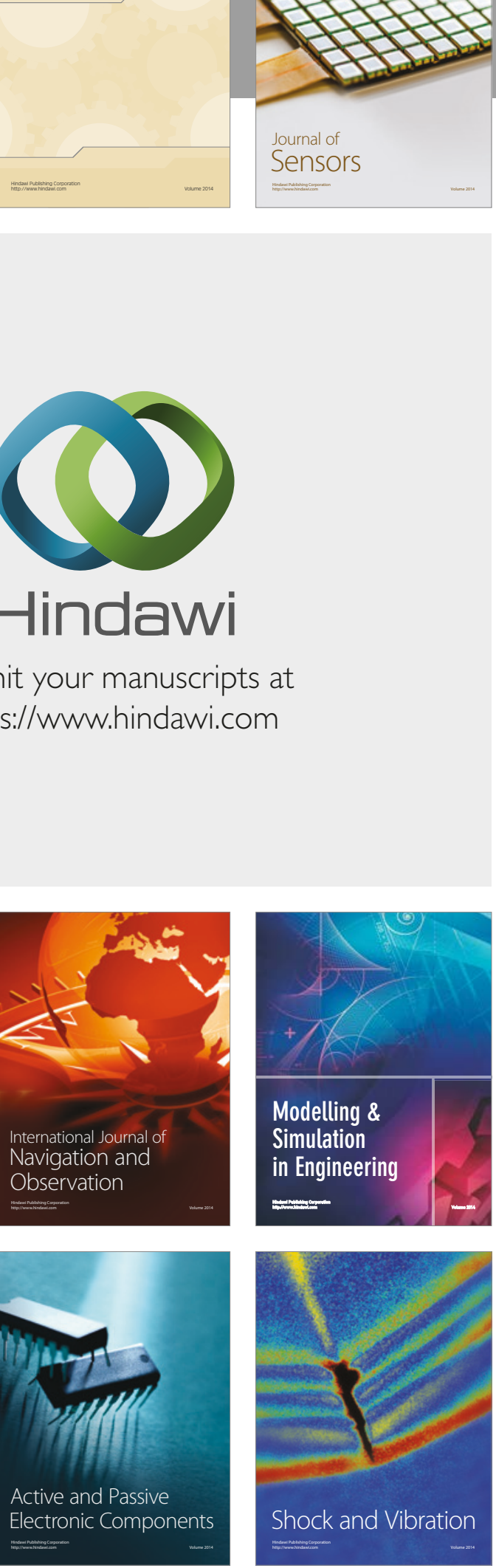
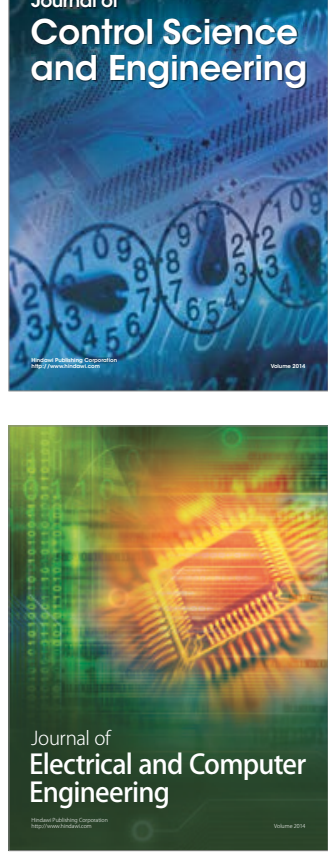

Distributed

Journal of

Control Science

and Engineering
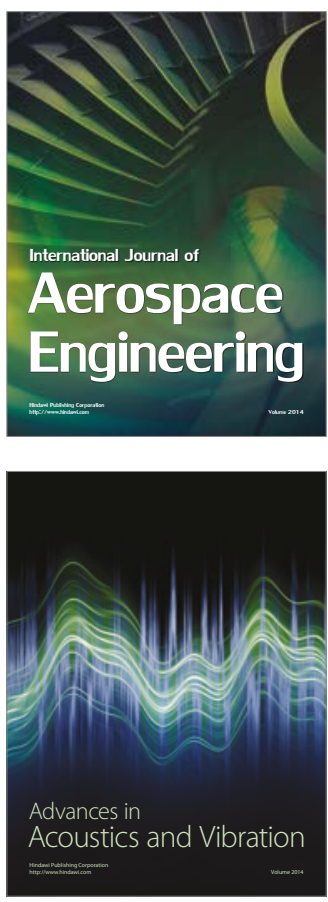

Sensor Networks 